\title{
COMMENTS
}

\section{PROTECTIVE ORDERS, PROPERTY INTERESTS AND PRIOR RESTRAINTS: CAN THE COURTS PREVENT MEDIA NONPARTIES FROM PUBLISHING COURT-PROTECTED DISCOVERY MATERIALS?}

\section{GILES T. COHEN†}

\section{INTRODUCTION}

On October 27, 1994, the Procter \& Gamble Company ("P \& G") filed suit against Bankers Trust Company, alleging that the defendant had engaged in "fraudulent conduct to induce [P \& G] to enter into and to remain in two complex leveraged derivative transactions" leading to losses of more than one hundred million dollars. ${ }^{1}$ On January 17,1995 , as part of the usual procedure in a case involving commercial clients, both parties stipulated to a protective order ${ }^{2}$ thereby putting confidential company documents under seal and protecting the materials produced during discovery. ${ }^{3}$ On September 12,1995 , though the complaint was filed under seal and was legally "hands off" to parties outside of the litigation, Business Week legal affairs editor Linda Himelstein obtained a copy of a 300-page amended complaint filed by $P$ \& $G$ in the United States District Court in the Southern District of Ohio. ${ }^{4}$

Himelstein, who had been investigating the lawsuit for an article for Business Week, received a copy of the complaint from a confiden-

† B.A. 1992, Cornell University; J.D. Candidate 1997, University of Pennsylvania. I would like to thank my father, N. Jerold Cohen, Chris Abbinante, Nina Abraham, Jeffrey Allen, Peter Blumberg and Pam Reichlin for their contributions to this piece. I would like to give thanks to my family and friends for their support and give special thanks to my sister, Pamela $C$. Torres, for her guidance throughout law school and her thoughtful suggestions for this Comment.

1 Procter \& Gamble Co. v. Bankers Trust Co., 900 F. Supp. 186, 187 (S.D. Ohio 1995); see also G. Bruce Knecht, $P \mathcal{E} \sigma^{2} G$ Can Add Racketeering to Its Claims: Pressure on Bankers Trust to Settle Case Is Raised by U.S. Judge's Ruling, WALL ST. J., Oct. 4, 1995, at A3.

${ }^{2}$ Protective orders generally impose confidentiality on materials exchanged during discovery. See infra note 13.

${ }^{3}$ See Procter E Gamble Co., 900 F. Supp. at 187.

${ }^{4}$ See John E. Morris, How Could Anyone Lose This Case?, AM. LAw., Nov. 1995, at 5, 62-63 (explaining how Himelstein obtained the document). 
tial source at Sullivan \& Cromwell, Bankers Trust's counsel. ${ }^{5}$ On September 13, when Business Week sought to publish a cover story based on the complaint, United States District Court Judge John Feikens faxed a restraining order just hours before the magazine's publication deadline. ${ }^{6}$ Business Week immediately sought expedited review from the Court of Appeals for the Sixth Circuit and the United States Supreme Court but was denied by both courts. ${ }^{7}$ On October 3, 1995, at the behest of Business Week, Judge Feikens held a hearing that ultimately led to his upholding the restraining order and, simultaneously, unsealing the protective order: this two-step approach maintained the injunction barring publication of the original confidential documents while allowing Business Week and others to make photocopies public. ${ }^{8}$ On March 5, 1996, in a case that generated widespread media interest and support, ${ }^{9}$ the United States Court of Appeals for the Sixth Circuit reversed Feikens's order on the grounds that it constituted an unconstitutional prior restraint. ${ }^{10}$

The Business Week situation is only the most recent instance of an evolving phenomenon: the tension between the American traditions of open trial proceedings and freedom of the press, and the application of the Federal Rules of Civil Procedure and their revised discovery provisions. ${ }^{11}$ Whereas the First Amendment has been

${ }^{5}$ See Milo Geyelin, Leaky Credibility: Big Law Firm's Gaffe Over Sealed Records Raises Troubling Issues, WALL ST. J., Oct. 4, 1995, at Al (discussing Himelstein's "source" at the New York law firm of Sullivan \& Cromwell who gave the documents to Business Week, "believ[ing] they were public").

${ }^{6}$ See Linda Himelstein, et al., The Story Behind the Bankers Trust Story, Bus. WK., Oct. 2, 1995, at 58 (describing how Business Week received and reacted to the restraining order).

7 See Procter E' Gamble Co., 900 F. Supp. at 188.

${ }^{8}$ See id. at 192-93.

${ }^{9}$ Business Week, with the support of media organizations including The New York Times, Time Warner, Dow Jones, ABC News and Newsweek, shipped emergency appeals to the Court of Appeals for the Sixth Circuit and then to the United States Supreme Court, urging that Feiken's order be overturned because of its disregard of precedent prohibiting prior restraints against the press. See Himelstein, supra note 6, at 59 . Conversely, Bankers Trust argued that because the materials were taken from sealed court records, Business Week should never have received them; Bankers Trust maintained that it would suffer "irreparable harm" if the materials were published. See id. at 58-59.

${ }^{10}$ See Procter \& Gamble Co. v. Bankers Trust Co., 78 F.3d 219, 224-27 (6th Cir. 1996).

${ }^{11}$ See Arthur R. Miller, Confidentiality, Protective Orders, and Public Access to the Courts, 105 HARV. L. REV. 427, 431-32 (1991) (arguing that "promoting increased public access to information by restricting the discretion of the courts to protect confidential information is ill-advised"). 
found to support public access to trial proceedings, ${ }^{12}$ Federal Rule of Civil Procedure 26(c) ("Rule 26(c)") grants broad discretion to the courts in implementing protective orders: ${ }^{13}$ Such orders allow the trial courts substantial leeway in restricting public access to pretrial discovery materials, which may implicate various other interests, including privacy interests and commercial interests. ${ }^{14}$ In Seattle Times Co. $v$. Rhinehart, ${ }^{15}$ the Supreme Court addressed this tension by emphasizing the private nature of pretrial discovery materials, effectively defeating First Amendment challenges to Rule 26(c) protective orders. ${ }^{16}$ While settling the constitutional question of the validity of restricting public access to discovery materials through protective orders, Rhinehart left open the question of whether media nonparties who obtain "protected" discovery materials

${ }^{12}$ See, e.g., Press-Enterprise Co. v. Superior Court, 478 U.S. 1, 10 (1986) [hereinafter Press-Enterprise Co.] (finding that the "First Amendment right of access. . . applies to preliminary hearings as conducted in California"); Richmond Newspapers, Inc. v. Virginia, 448 U.S. 555, 580 (1980) (finding a First Amendment right to attend criminal trials).

${ }^{13}$ Rule 26(c) provides, in relevant part:

Upon motion by a party or by the person from whom discovery is sought, accompanied by a certification that the movant has in good faith conferred or attempted to confer with other affected parties in an effort to resolve the dispute without court action, and for good cause shown, the court in which the action is pending or alternatively, on matters relating to a deposition, the court in the district where the deposition is to be taken may make any order which justice requires to protect a party or person from annoyance, embarrassment, oppression, or undue burden or expense, including one or more of the following:

(1) that the disclosure or discovery not be had;

....

(4) that certain matters not be inquired into, or that the scope of the disclosure or discovery be limited to certain matters;

....

(7) that a trade secret or other confidential research, development, or commercial information not be revealed or be revealed only in a designated way;

....

FED. R. CrV. P. 26(c).

${ }^{14}$ The Advisory Committee's notes to Rule 26(c) recognize the court's discretion with regard to imposing protective orders on discovery material, noting that the court must "weigh [a litigant's] claim to privacy against the need for disclosure." FED. R. Crv. P. 26(c) advisory committee's notes (1970 amendments).

${ }^{15} 467$ U.S. 20 (1984).

${ }^{16}$ See id. at 33-34 (noting that "restraints placed on discovered, but not yet admitted, information are not a restriction on a traditionally public source of information" and therefore "implicate[] the First Amendment rights of the restricted party to a far lesser extent than would restraints on dissemination of information in a different context"). 
through mistake or illegitimate means are likewise bound by such an order. ${ }^{17}$

This Comment proposes that a court may, under certain circumstances, utilize its injunctive power to prevent confidential discovery materials under a protective order from being published by a media nonlitigant. ${ }^{18}$ Because this position seems to fly in the face of First Amendment considerations, Part I of this Comment will examine the tension between the clear presumption against suppression of speech and prior restraints highlighted in such seminal cases as New York Times Co. v. United States ${ }^{19}$ and Nebraska Press Ass'n. v. Stuart, ${ }^{20}$ and the protection afforded to confidential discovery materials that are under seal in Seattle Times Co. $v$. Rhinehart. ${ }^{21}$ Part II will examine the theoretical arguments supporting the extension of protective orders to nonparties. These policy arguments, which include the litigants' privacy and property interests and the court's interest in an efficient process, are critical because they counter the strong First Amendment considerations in this area.

Part III demonstrates how these policy arguments shape legal doctrine enabling a court to establish a property right in certain intangible commercial information. ${ }^{22}$ The intangible property interest is crucial because by establishing a property interest in information covered by a protective order, a court may justify a restraining order on the grounds of protecting private property, even in the face of a legitimate First Amendment claim. This conflict caused by the attempt to balance private property rights and First

${ }^{17}$ See id. at 32 (finding that a litigant has no First Amendment right of access "to information made available only for the purposes of trying his suit," but not addressing the question of nonlitigant access).

${ }^{18}$ Because the considerations and interests vary tremendously depending on the type of nonparty who has information subject to a protective order, this Comment is limited in scope to the media nonparty. Other nonparties, such as successive litigants or other interested individuals, will not be examined.

19403 U.S. 713, 714 (1971) (quoting Bantam Books, Inc. v. Sullivan, 372 U.S. 58, 70 (1963) for the proposition that "[a]ny system of prior restraints of expression . . . bear[s] a heavy presumption against its constitutional validity").

20427 U.S. 539, 539 (1976) (asserting that "the barriers to prior restraint remain high" and concluding that the burden required to impose a prior restraint was not met in that case).

${ }^{21}$ Rhinehart, 467 U.S. at 37 (holding that where a "protective order is entered on a showing of good cause as required by Rule $26(\mathrm{c})$, is limited to the context of pretrial civil discovery, and does not restrict the dissemination of the information if gained from other sources," the order is consistent with the First Amendment).

${ }^{22}$ Proprietary interests in information may constitute patents, copyrights, or trade secrets and other confidential business information. See infra Part II.C. 
Amendment considerations has developed into a highly malleable and confused area of Supreme Court jurisprudence. Part IV proposes a standard for enforcing protective orders against media nonlitigants, a standard determined by the property interest in the information sought to be protected.

\section{PROTECTIVE ORDERS, NONPARTIES AND THE FIRST AMENDMENT CHALLENGE: SETTING THE LEGAL BACKDROP}

The language of the First Amendment is clear: "Congress shall make no law ... abridging the freedom of speech, or of the press." ${ }^{23}$ A pervasive tension exists, however, between the applicability of the First Amendment to judicial proceedings and the authority. of the courts to remove documents from public access. ${ }^{24}$ Whereas the United States has a longstanding tradition of allowing the public to view judicial proceedings and daily court activities, ${ }^{25}$ this right of access is not absolute. ${ }^{26}$ The justice system recognizes several circumstances-such as attorney-client privilege,${ }^{27}$ settlement negotiations, ${ }^{28}$ grand jury proceedings ${ }^{29}$ and discovery ${ }^{30}$ - where confidentiality is not only allowed, but is necessary. ${ }^{31}$ Moreover,

${ }^{23}$ U.S. CONST. amend. I.

${ }^{24}$ See Katherine W. Pownell, Comment, The First Amendment and Pretrial Discovery Hearings: When Should the Public and Press Have Access?, 36 UCLA L. REV. 609, 610 (1989) (arguing that the First Amendment presumption of public access to judicial proceedings and the broad discretion courts have in restricting access to pretrial discovery materials are in conflict).

${ }^{25}$ See Press-Enterprise Co., 478 U.S. 1, 7 (1986) ("[O]ne of the important means of assuring a fair trial is that the process be open to neutral observers."); Richmond Newspapers, Inc. v. Virginia, 448 U.S. 555, 570-71 (1980) (stating that public access to criminal trials is essential to maintain confidence in the justice system); Miller, supra note 11, at 428 (stating that "[b]y longstanding tradition, the American public is free to view the daily activities of the courts").

${ }^{26}$ See Press-Enterprise Co., 478 U.S. at 9 ("But even when a right of access attaches, it is not absolute.").

${ }^{27}$ See United States v. Noriega, 917 F.2d 1543, 1548 (11th Cir. 1990) ("The general public has no right of access to private communications between a defendant and his counsel.").

${ }^{28}$ See Allen v. Colgate Palmolive Co., No. 79 Civ. 1076 (CSH), 1986 WL 8218, at *4 (S.D.N.Y. Feb. 20, 1996) (upholding a settlement agreement containing confidentiality provisions).

${ }^{29}$ See United States v. Sells Eng'g, Inc., 463 U.S. 418, 424 (1983) (noting the interests served by "safeguarding the confidentiality of grand jury proceedings") (quoting Douglas Oil Co. v. Petrol Stops Northwest, 441 U.S. 211, 218-19 (1979)).

${ }^{30}$ See Seattle Times Co. v. Rhinehart, 467 U.S. 20, 33 (1984) (noting that "pretrial depositions and interrogatories are not public components of a civil trial").

${ }^{31}$ See Miller, supra note 11, at 429 (discussing situations where confidentiality is recognized and enforced by the courts). 
trial judges are given broad discretion to determine whether to allow any public access to materials for litigation and settlement negotiations. ${ }^{32}$

The tension between presumed "openness" and court-enforced confidentiality is even more pronounced when one of the parties affected is the press. ${ }^{33}$ When a protective order is imposed on discovery materials and publication or dissemination of the material is prohibited, this order is analogous to a prior restraint ${ }^{34}$ on the litigant's speech. ${ }^{35}$ As the Supreme Court has previously recognized, prior restraints are "one of the most extraordinary remedies known to our jurisprudence"36 and are particularly disfavored. ${ }^{37}$ In view of this longstanding judicial hostility to prior restraints and the highly correlative nature of prior restraints and protective orders, the situation in which a member of the media has acquired courtprotected discovery materials pertaining to litigation of which it is not a party requires an examination of the legal doctrine covering protective orders and prior restraints on the media.

\section{A. Pretrial Discovery Materials Are Not Presumptively Public- Seattle Times Co. v. Rhinehart}

Prior to Seattle Times Co. v. Rhinehart, ${ }^{38}$ many courts and commentators debated whether the First Amendment limited the right to enforce a protective order against the parties themselves. ${ }^{39}$

${ }^{32}$ See E.I. Du Pont de Nemours Powder Co. v. Masland, 244 U.S. 100, 103 (1917) (observing that trial judges have great discretion "to determine whether, to whom, and under what precautions" certain materials and activities need to be revealed).

${ }^{33}$ Note, for example, the unified media response to the case of McGraw-Hill Cos. v. Procter \& Gamble Co., 116 S. Ct. 6 (1995) (mem.), as evidenced by the amicus brief supportive of McGraw-Hill Cos. by Dow Jones \& Co., The Cincinnati Enquirer, The Los Angeles Times, Newsday and the American Society of Newspaper Editors. See Proctor \& Gamble Co. v. Bankers Trust Co., 78 F.3d 219, 232 (6th Cir. 1996) (Brown, J., concurring); see also supra note 9.

${ }^{34}$ A prior restraint is a technical term in First Amendment law that refers to the "imposition of a restraint on a publication before it is published." BLACK'S LAW DICTIONARY 1194 (6th ed. 1990).

${ }^{35}$ See In re Halkin, 598 F.2d 176, 196 (D.C. Cir. 1979) (finding that a protective order prohibiting publication was deficient because an order restricting a litigant's speech should only be permitted where a prior restraint would be justified). But see Seattle Times Co. v. Rhinehart, 467 U.S. 20 (1984) (upholding a protective order that prohibited publication of the membership of a religious organization).

${ }_{36}$ Nebraska Press Ass'n v. Stuart, 427 U.S. 539, 562 (1976).

${ }^{37} \mathrm{See} i d$. at 559 (finding that "prior restraints on speech and publication are the most serious and least tolerable on First Amendment rights").

${ }^{38} 467$ U.S. 20 (1984).

${ }^{39}$ Compare In re Halkin, $598 \mathrm{~F} .2 \mathrm{~d}$ at 196 (invalidating a protective order on the 
Protective orders were analogized to "prior restraints" on free speech of the litigants, and the orders were therefore arguably subject to strict scrutiny. ${ }^{40}$ In 1984, the Supreme Court firmly addressed the issue of a litigant's First Amendment rights with regard to a protective order in Rhinehart.

In Rhinehart, a religious organization and its spiritual leader brought a defamation action in a Washington state court against two newspapers that had written stories about them. ${ }^{41}$ In response to the defendants' discovery request seeking lists of the organization's members and contributors, the plaintiffs sought a protective order to limit the use of the lists outside the trial. ${ }^{42}$ Based in part on the defendants' stated intent to continue publishing articles about the plaintiffs using information gained in discovery, the trial court issued a protective order that "prohibited [the newspapers] from publishing, disseminating, or using the information in any way except where necessary to prepare for and try the case." ${ }^{33}$ Because the newspapers had access to the discovery materials for trial use, but were forbidden from publishing or disseminating the material, the order implicated a First Amendment prior restraint.

The Supreme Court emphatically endorsed the constitutionality of protective orders, stating that pretrial discovery was "not [a] public component[] of a civil trial"44 and reasoning that such an order "did not involve a restriction on the use of a traditionally public source of information." ${ }^{45}$ Moreover, the Court noted that it had

ground that it would constitute an unjustified prior restraint) with Richard L. Marcus, Myth and Reality in Protective Order Litigation, 69 CORNELL L. REV. 1, 15 (1983) ("The reality against which constitutional and common law issues should be assessed is, therefore, a reality of confidentiality-one that is inherent in the discovery process and essential if parties are to avoid the unwarranted harm that may result from the intrusiveness of modern discovery.").

${ }^{40}$ See Michael Dore, Confidentiality Orders-The Proper Role of the Courts in Providing Confidential Treatment for Information Disclosed Through the Pra-Trial Discovery Process, 14 NEW ENG. L. REV. 1, 13-14 (1978) (arguing that "[o]nce access to the purportedly confidential information has been obtained, judicial restrictions on the use of such information must meet the very strict requirements justifying any other type of prior restraint").

${ }^{41}$ See Rhinehart, 467 U.S. at 22-23.

42 See id. at 25.

${ }^{43}$ Id. at 27.

41. at 33. The Court went on to explain the "private" nature of discovery in a footnote, stating that "[d]iscovery rarely takes place in public." Id. at 33 n.19. Moreover, the Court stated that "to the extent that courthouse records could serve as a source of public information, access to that source customarily is subject to the control of the trial court." Id.

${ }^{45}$ Pownell, supra note 24, at 622. 
previously decided that a litigant has no First Amendment right of access to information made available only for purposes of trying a suit. ${ }^{46}$ Thus, the Court reasoned that "continued court control over the discovered information does not raise the same specter of government censorship that such control might suggest in other situations." ${ }^{\prime 7}$

In upholding the Washington trial court's ability to impose and enforce a protective order, ${ }^{48}$ the Court emphasized the interest of the trial court in maintaining control over the litigation process. ${ }^{49}$ The Court noted that discovery has a "significant potential for abuse," which may encompass not only delay and extra expense but also the acquisition of sensitive information that "could be damaging to reputation and privacy" if released. ${ }^{50}$ Liberal discovery is not provided to litigants to achieve this end but "for the sole purpose of assisting in the preparation and trial, or the settlement, of litigated disputes."51 The opinion explained that because of the liberal discovery rules, "it is necessary for the trial court to have the authority to issue protective orders conferred by Rule 26(c)."52

Given the weight afforded to a trial court's management of the litigation process, the Court concluded that protective orders do not offend the First Amendment when "a protective order is entered on a showing of good cause as required by Rule 26(c), is limited to the context of pretrial civil discovery, and does not restrict the dissemination of the information if gained from other sources." 53 While the

${ }^{46}$ See Rhinehart, 467 U.S. at 32 ("'The right to speak and publish does not carry with it the unrestrained right to gather information." (quoting Zemel v. Rusk, 381 U.S. 1, 16-17 (1965))).

47 Id.

${ }^{48}$ It should be noted that the Supreme Court upheld the Washington trial court's use of a protective order under the Washington discovery rule, WASH. SUPER. CT. CIV. R. 26(c), and not the Federal Rules of Civil Procedure. See Rhinehart, 467 U.S. at 34. However, the ruling in Rhinehart is applicable beyond Washington's borders because the Washington Rule is identical to Federal Rule 26(c). See Robert C. Post, The Management of Speech: Discretion and Rights, 1984 SUP. CT. REV. 169, 184 ("The Washington Rule was in fact issued by the Supreme Court of Washington, which simply copied it verbatim from the federal rule promulgated by the United States Supreme Court.").

${ }^{49}$ See id. at 196 ("[T] interests nor the diminishment of litigants' First Amendment interests, but rather the Court's perception that discretionary authority to issue restraining orders is essential for the administration of pretrial discovery.").
${ }^{50}$ Rhinehart, 467 U.S. at $34-35$.
${ }^{51} \mathrm{Id}$. at 34 .
${ }^{52} I d$.
${ }^{53} I d$. at 37 . 
Rhinehart rule did not limit the newspaper's right to publish material obtained outside of the discovery process, as a practical matter the ruling severely hampered this possibility because of the difficulty of proving that subsequently published information had been obtained by a means other than the discovery process. ${ }^{54}$ Lower courts have subsequently defined Rhinehart to uphold protective orders as consistent with the First Amendment. ${ }^{55}$

\section{B. The First Amendment, Nonparties and Prior Restraint}

Rhinehart established the constitutionality of protective orders with regard to a First Amendment challenge from parties to the litigation. When the entity sought to be restrained from disseminating or publishing the discovery information is not a party to the litigation, and has acquired the information notwithstanding the protective order, enforcing a protective order against such an entity resurrects First Amendment prior restraint analysis. ${ }^{56}$ The argument from the side of First Amendment proponents is simple: a media nonparty who has acquired newsworthy information is protected by judicial precedent mandating that "[a]ny prior restraint on expression comes to this Court with a 'heavy presumption' against its constitutional validity."

54 See Richard L. Marcus, The Discovery Confidentiality Controversy, 1991 U. ILL. L. REv. 457, $460 \mathrm{n} .2$ (noting that proving the independent procurement of sources in the publishing context presents difficulties similar to those involved in proving the independence of sources in criminal cases where a Fourth Amendment violation has been found).

While the method by which the information was acquired is only a minor point in Rhinehart, it may play a major role in determining how a protective order is applied to nonparties. See infra Part III.B.

${ }^{55}$ See, e.g., Cipollone v. Liggett Group, Inc., 785 F.2d 1108, 1119 (3d Cir. 1986) (arguing that there is "no room for lower courts to consider [F]irst [A]mendment factors in fashioning or reviewing Rule 26(c) orders. ... [T] he [F]irst [A] mendment is simply irrelevant to protective orders in civil discovery"); George W. Prescott Publishing Co. v. Register of Probate, 479 N.E.2d 658, 662 (Mass. 1985) (“Moreover, the United States Supreme Court has recently held that the impoundment of material obtained in the course of pretrial discovery, if supported by 'a showing of good cause,' does not violate the First Amendment." (quoting Rhinehart, 467 U.S. at 37)).

${ }^{56}$ See Brief of Appellant The McGraw-Hill Companies at 15, Procter \& Gamble Co. v. Bankers Trust Co., 78 F.3d 219 (6th Cir. 1996) (No. 95-4078) [hereinafter Brief of Appellant The McGraw-Hill Cos.] (arguing that a nonparty publisher who already has obtained the documents outside the discovery process is a victim of a prior restraint if a protective order is enforced).

${ }^{57}$ Nebraska Press Ass'n v. Stuart, 427 U.S. 539, 558 (1976) (citations omitted). It is important to emphasize that Rhinehart does not apply and the protective order cannot be enforced where the media (or even a media litigant) has obtained the disputed information independent of the discovery process. See Rhinehart, 467 U.S. at 37. 
While the presumption against prior restraint validity is not absolute, the Supreme Court has indicated that there is an "extremely narrow class of cases" where the First Amendment will tolerate a prior restraint. ${ }^{58}$ "[O]nly when the Nation is 'at war," or when publication of information such as number and location of troops is at issue, has a prior restraint been constitutionally appropriate. ${ }^{60}$ In fact, the right to publish has prevailed in cases involving competing interests of a criminal defendant's Sixth Amendment right to a fair trial, ${ }^{61}$ a rape victim's claim to confidentiality, ${ }^{62}$ and financial harm to a company or business. ${ }^{63}$

Moreover, the Court has held that the existence of other postpublication civil and criminal remedies makes prior restraints even more constitutionally offensive: "If it can be said that a threat of criminal or civil sanctions after publication 'chills' speech, prior restraint 'freezes' it at least for the time." ${ }^{64}$ It is therefore arguable that the media nonparty who has acquired the sealed discovery information could only be punished post-publication, if at all. ${ }^{65}$ For the media nonparty with information in hand, the argument goes, the First Amendment provides all the protection necessary to defeat the enforcement of a protective order. ${ }^{66}$

For the purposes of this Comment the information will be assumed to have been acquired as part of the discovery process. See infra Part IV.A.1.

${ }_{58}$ New York Times Co. v. United States, 403 U.S. 713, 726 (1971).

${ }^{59}$ Id. (quoting Schenck v. United States, 249 U.S. 47, 52 (1919)).

${ }^{60}$ See Near v. Minnesota, 283 U.S. 697, 716 (1931) ("No one would question but that a government might prevent . . . the publication of . . . the number and location of troops." (dictum)).

${ }^{61}$ See Nebraska Press Ass'n, 427 U.S. at 562-63 (allowing publication of a criminal defendant's murder confession).

${ }^{62}$ See The Florida Star v. B.J.F., 491 U.S. 524 (1989); Cox Broadcasting Corp. v. Cohn, 420 U.S. 469 (1975).

${ }^{6 s}$ See CBS Inc. v. Davis, 114 S. Ct. 912, 914 (1994) (finding that economic harm to a business could not justify a prior restraint).

${ }^{64}$ Nebraska Press Ass'n, 427 U.S. at 559; see also CBS Inc., 114 S. Ct. at 914 ("Subsequent civil or criminal proceedings, rather than prior restraints, ordinarily are the appropriate sanction ....").

${ }^{65}$ See Brief of Appellant The McGraw-Hill Cos., supra note 56, at 28. For example, it may be more appropriate to punish the party that leaked the sealed information than to restrain the media nonparty from publishing. See id. This alternative, however, provides little consolation to the parties who are affected by the dissemination and it would have little force if the "source" of the leak were the court itself.

${ }^{66}$ See id. at 15. 


\section{The Protective ORder Debate: VALUES IMPLICATED BY NONPARTY DISSEMINATION}

Given the Supreme Court's adamant protection of the First Amendment right against suppression of speech ${ }^{67}$ and the perceived deference granted to trial courts in enforcing protective orders in light of the First Amendment under Rhinehart, the law is at a crossroads. A protective order can only be extended until it becomes an unconstitutional prior restraint, but if it is not extended far enough, it may lose any force it once had. ${ }^{68}$ In order to show that, under certain circumstances, protective orders appropriately bind media nonparties who have gained access to confidential discovery materials, this Comment will first examine the policy arguments in favor of allowing protective orders to bind media nonparties who have gained such access.

\section{A. Efficiency in Court Process}

The substantive value of protective orders is best understood in relation to their procedural role under the Federal Rules of Civil Procedure ("Federal Rules"). The Federal Rules' discovery provisions were designed to broaden the availability of discovery and to facilitate the free exchange of relevant information between litigants. ${ }^{69}$ This emphasis on broad disclosure led to an increased burden and expense on both the parties and the courts, thus conflicting with the Federal Rules' fundamental goal of the "just, speedy, and inexpensive determination of every action."70 Consequently, lower courts and litigants have increasingly relied on protective orders to restrict the dissemination of information obtained through discovery, thereby expediting the process and minimizing the burden of litigating discovery issues. ${ }^{71}$ Moreover, protective orders further the goal of maximized efficiency of the court process by providing parties with effective safeguards from "improper" use of discovery. ${ }^{72}$

\section{${ }^{67}$ See supra Part I.B.}

${ }^{68}$ See Procter \& Gamble Co. v. Bankers Trust Co., 900 F. Supp. 186, 193 (S.D. Ohio 1995) ("The efficient administration of discovery necessitates that [the trial court] be able to prevent Business Week from publishing what never would have existed independently of the discovery process.").

${ }^{69}$ See 8 Charles A. WRIGHT \& ARTHUR R. MILlER, FEDERAL PRACTICE AND PROCEDURE $\$ 2002$ (1994) (describing the history of the Federal Rules of Civil Procedure discovery provisions).

${ }^{70}$ FED. R. CIV. P. 1.

71 See Marcus, supra note 39, at 2.

72 See FED. R. CIV. P. 26 advisory committee's notes (1983 amendments) ("Thus the 
If parties are unable to rely on the force of a protective order to seal discovery information, then the orders become valueless. If parties know that compliance with a discovery request, even with a protective order, could result in uncontrolled dissemination of private or financially-valuable information, discovery requests would likely be contested more frequently to prevent disclosure. ${ }^{73}$ Given that there has been a recent proliferation of protective orders ${ }^{74}$ and that the trial courts currently enjoy broad discretion in granting such orders, ${ }^{75}$ any diminishment in the effectiveness of protective orders, either real or apparent, would severely hinder the fundamental goal of an efficient trial process.

One repercussion of allowing only litigants to rely on the power of a protective order, thereby undercutting an order's effectiveness, is the risk that the scope of the discovery process may be curtailed by the lower courts or the parties if either are persuaded that confidentiality demands such restriction. ${ }^{76}$ By limiting the scope of discovery to protect commercially valuable or private information that cannot be effectively safeguarded with an order, courts are supported both by judicial precedent ${ }^{77}$ and by the Federal Rules, which explicitly acknowledge a court's power to refuse discovery requests. ${ }^{78}$ However, by choosing to limit discovery rather than rely on an ineffective protective order, the courts would undermine the fundamental

spirit of the rules is violated when advocates attempt to use discovery tools as tactical weapons rather than to expose the facts and illuminate the issues by overuse of discovery or unnecessary use of defensive weapons or evasive responses.").

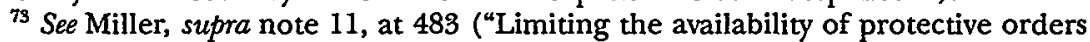
makes the discovery process more contentious, protracted and expensive.").

${ }^{74}$ See Zenith Radio Corp. v. Matsushita Elec. Indus. Co., 529 F. Supp. 866, 889 (E.D. Pa. 1981) (noting that "[p]rotective orders have been used so frequently that a degree of standardization is appearing").

${ }^{75}$ See Marcus, supra note 39, at 2 ("The good cause standard gives courts very broad discretion to tailor protective provisions to fit the needs of the case.").

${ }^{76}$ See MANUAL FOR COMPLEX Litigation $\S 21.431$ n.159 (3d ed. 1995) ("If a party freely disclosed information without contest based on the premise that it would remain confidential, subsequent dissemination may be unfair and may, in the long run, reduce other litigants' confidence in protective orders, rendering them less useful as a tool for preventing discovery abuse and encouraging more strenuous objections to discovery requests.").

${ }^{77}$ See In re San Juan Star Co., 662 F.2d 108, 115 (1st Cir. 1981) (noting that a trial judge "might well refuse to allow the discovery to proceed at all"); In re Halkin, 598 F.2d 176, 190 (D.C. Cir. 1979) (stating that there is no constitutional right to discovery).

${ }^{78}$ See FED. R. Crv. P. 26(c) (1) (allowing a lower court to make an order "that the discovery not be had"). 
purpose of discovery, which is to make available the "' $[\mathrm{m}]$ utual knowledge of all the relevant facts gathered by both parties."

The parties may also frustrate the discovery process by failing to provide information that otherwise, if disclosed, might have been protected. ${ }^{80}$ Currently, parties forced into litigation are wary of opponents who use the trial process for nonlitigation purposes. ${ }^{81}$ As a result, discovery abuse involving nondisclosure or improper discovery requests is a difficulty faced by both parties and courts even with protective orders in place. ${ }^{82}$ Litigants' apprehension will intensify, and failure to comply with discovery will increase if the effectiveness of the order diminishes. ${ }^{83}$

Another consequence of limiting protective-order enforcement is the effect it may have on current settlement negotiations. ${ }^{84}$ The efficient operation of the courts is supported by an independently valid policy interest in promoting settlement. ${ }^{85}$ Although it is questionable whether settlement negotiations are severely affected by protective orders, ${ }^{86}$ secrecy can be critical and violation of protective orders by nonparties will undoubtedly affect opportunities for settlement. Moreover, opportunity to avoid the negative publicity associated with disclosing confidential information at trial may be an inducement to pretrial settlement. ${ }^{87}$ In this situation, where the settlement proposal is conditioned on the return of the discovered

${ }^{79}$ FED. R. CIV. P. 26 advisory committee's notes (1983 amendments) (quoting Hickman v. Taylor, 329 U.S. 495, 507 (1947)).

${ }^{80}$ See Marcus, supra note 39, at 21.

81 See Marrese v. American Academy of Orthopaedic Surgeons, 706 F.2d 1488, 1495 (7th Cir. 1983) (observing that discovery of confidential information is sometimes sought for the ulterior motive of forcing the disclosing party "to settle [the suit] in order not to have to disclose sensitive materials"), rev'd on other grounds, 470 U.S. 373 (1985) .

82 See Marcus, supra note 54, at 486.

${ }^{83}$ See Marcus, supra note 39, at 22 ("[A] reliable protective order prohibiting misuse of information obtained through discovery both placates the person subject to discovery and reduces the temptation to disregard the obligation to produce the requested information.").

${ }^{84}$ See Miller, supra note 11 , at 486 (stating that "if the effectiveness of the protective order cannot be relied on, its capacity to motivate settlement will be compromised").

${ }^{85}$ See id.; see also Minneapolis Star \& Trib. Co. v. Schumacher, 392 N.W.2d 197, 205 (Minn. 1986) (asserting that " $[t]$ he philosophical reasoning behind allowing private settlements also leads to the conclusion that such agreements should remain private").

${ }^{86}$ See Marcus, supra note 39, at 27 n.112 (noting that the 1970 amendments to the Federal Rules acknowledge contrary arguments to the settlement debate).

${ }^{87}$ See id. at 28 (observing that "[a] party may desire a settlement in part to avoid a trial at which confidential information will be disclosed"). 
materials, ${ }^{88}$ an effective protective order is invaluable to settlement negotiations. It would seem even more likely, then, that where both parties have stipulated to put discovery materials under seal, the dissemination of the sealed documents by a party outside the litigation would severely hamper the settlement negotiation process. If the settlement process is affected, it therefore follows that the policy of a smooth and efficient judicial process is also disrupted.

\section{B. Privacy Interests in Protective-Order Content}

In examining the substantive value of protective orders, the interest most clearly affected by uncontrolled dissemination by a nonparty is the litigant's privacy. ${ }^{89}$ The Supreme Court has characterized this interest as "a zone of privacy surrounding every individual, a zone within which the State may protect him from intrusion by the press, with all its attendant publicity." 90 The privacy right of a litigant may be affected because of the nature of compelled discovery and the lack of a distinction in the Federal Rules between public and private information. ${ }^{91}$ This is especially true for a defendant who is "dragged" into court and is then faced with compulsory disclosure of private information. The Court has not overlooked this potential for abuse in concluding that litigants have privacy interests in the information obtained during discovery and that "[t]he government clearly has a substantial interest in preventing this sort of abuse of its processes." ${ }^{\prime 2}$

The notion that a litigant does not give up her right of privacy simply by walking through the courthouse door is also consistent with

${ }^{88}$ See id. (asserting that "a party is likely to condition his willingness to settle upon the entry of a court order prohibiting the disclosure of ... information obtained through discovery).

${ }^{89}$ See Catherine Yang, Commentary: A Disturbing Trend Toward Secrecy, Bus. WK., Oct. 2, 1995, at 60, 60 ("Companies, of course, have many legitimate reasons for wanting confidentiality, including the protection of privacy and trade secrets.").

${ }^{90}$ Cox Broadcasting Corp. v. Cohn, 420 U.S. 469, 487 (1975).

${ }^{91}$ See Seattle Times Co. v. Rhinehart, 467 U.S. 20, 35 (1984) ("The Rules do not distinguish between public and private information.").

${ }^{92}$ Id. The Court also noted that Federal Rule 26(c) does not explicitly reference privacy interests but that they are "implicit in the broad purpose and language of the Rule." Id. at 35 n.21.

Rhinehart also suggests that privacy rights encompass information beyond that which is intuitively "private" such as information regarding financial affairs of businesses, marketing strategies and other sensitive commercial information. Id. at 26-27 (noting that public release of the donor lists would not only adversely affect the Aquarian Foundation membership and income but also subject its members to attacks, threats and additional harassment). 
the traditional purpose of the Federal Rules to facilitate the free exchange of information. ${ }^{93}$ In expanding the scope of discovery to promote access to relevant information, the drafters of the Federal Rules never intended to undermine the litigant's interest in privacy. ${ }^{94}$ Even though a party may have the right to discover information that is relevant to the allegations made, it does not follow that the public has a concomitant "right to know" all of the same information. ${ }^{95}$ This is why Federal Rule 26(c) indicates that a lower court has discretion to impose a protective order that may implicitly protect privacy interests. ${ }^{96}$

Given that the Court has acknowledged a privacy interest in the discovered information, and that the Federal Rules are consistent with this privacy right, the question is reduced to this: Should the privacy interests of litigants who have agreed to a protective order be subordinate to the interests of the media nonparty who wishes to disseminate that information? The media nonparty's interest would have to be characterized as the "public interest"; the process of characterizing the media nonparty's interest, however, is problematic. ${ }^{97}$ One would have to define the "public interest" and then presume that the public has an interest in the information disclosed. ${ }^{98}$ While the public may have an interest in certain cases, ${ }^{99}$ it is doubtful that the public has an interest in the technical details exchanged in most lawsuits. ${ }^{100}$ More significantly, the power to

${ }^{93}$ See 8 WRIGHT \& MILLER, supra note 69 and accompanying text.

${ }^{94}$ See Miller, supra note 11, at 466 ("The drafters had no intention of using these procedures to undermine privacy; nor were they expanding discovery in the name of promoting public access to information.").

${ }^{95}$ See David J. Beck \& Amy M. Decker, Protective Orders and Confidentiality, in Managing Complex Litigation 65, 73 (Tort and Ins. Practice Section, ABA ed., 1992).

${ }^{96}$ See FED. R. Crv. P. 26(c) (noting that a court "may make any order" to protect a litigant from "embarrassment"). The Supreme Court has acknowledged this justification for imposing a protective order. See Rhinehart, 467 U.S. at $35 \mathrm{n} .21$ (stating that privacy interests are "implicit" in the protection offered by Federal Rule 26).

97 See Miller, supra note 11, at 467 (noting that "public interest" embraces curiosity and voyeurism as well as legitimate concerns of the public involving, for example, health and safety).

${ }^{98}$ See Marcus, supra note 54, at 479 ("[T] he public's actual interest in information about other people may not accord with an informed observer's belief about what the public should find interesting.").

${ }^{99}$ See $i d$. (noting that the public would more likely be interested in the depositions in the lawsuit involving Donald and Ivana Trump than they would be in a typical accident suit).

${ }^{100}$ See Miller, supra note 11, at 467 ("The vast majority of litigation is quite mundane, is exceedingly complex and technical, or deals exclusively with the 
distinguish cases that involve the "public interest" from those cases that do not would fall into the hands of the court on an ad hoc basis. Such review would require a court to perform the formidable task of distinguishing between the "public interest" and the public's mere curiosity. ${ }^{101}$

\section{Property Rights in Trade Secrets and Commercially Valuable Information}

Uncontrolled dissemination of confidential information by a media nonparty will also jeopardize the litigants' property rights to manage their information..$^{102}$ Commercially valuable information, or "intellectual property," has been increasingly considered a business asset that is closely tied to a business's competitive strategy. ${ }^{103}$ Once proprietary information is disclosed to a competitor, the competitive edge it previously afforded will be lost and trade secret law will not protect the secret from further dissemination. ${ }^{104}$ Proprietary-information owners, then, have a legitimate justification for seeking enforcement of an effective protective order. ${ }^{105}$

Given the increased recognition of the proprietary value of intangible commercially valuable information, ${ }^{106}$ it is not surprising that the Supreme Court has acknowledged the status of confidential information as property. ${ }^{107}$ This identification of a property

application of arcane principles of law in factual situations far removed from daily life.").

${ }^{101}$ It should also be noted that Congress is in a better position than the courts not only to identify those situations that may pique the public's interest, but also to determine when the public interest in dissemination outweighs the privacy interests of the litigant. See id. at 466 n.203 (noting that the antitrust statutes that make pretrial antitrust proceedings presumptively public are examples of Congress's ability to balance these competing interests).

102 See id. at 467.

${ }^{103}$ See James H.A. POOley, Trade Secrets at xi (1987) (noting that one's "competitive edge" is closely linked to developing and protecting business information such as "marketing studies, customer lists and business plans").

${ }^{104}$ See Note, Trade Secrets in Discovery: From First Amendment Disclosure to Fifth Amendment Protection, 104 HARV. L. REV. 1330, 1330 (1991) [hereinafter Trade Secrets in Discovery].

${ }^{105}$ Some commentators have argued that using discovery in litigation to obtain confidential information from a competitor can be analogized to a "taking" in the property context. See id. at 1336-45; see also Gregory Gelfand, 'Taking' Information Property Through Discovery, 66 WASH. U. L.Q. 703 (1988).

${ }^{106}$ See POOLEY, supra note 103, at xi-xiv (discussing the effects of the technological revolution on the rise of proprietary data).

${ }^{107}$ See, e.g., Carpenter v. United States, 484 U.S. 19, 26 (1987) (noting that confidential business information is property); Ruckelshaus v. Monsanto Co., 467 U.S. 
interest in certain information reflects the economic and legal arguments that property status will promote socially useful behavior. ${ }^{108}$ Exclusive property rights to commercially valuable information, therefore, provide an incentive to develop, trade and produce such information, which will ultimately benefit others. ${ }^{109}$ Furthermore, the dependence of today's economy on the technological "revolution" and its advances in trading, communicating and processing information have made confidentiality of proprietary business information paramount. ${ }^{110}$

If protective orders were unable to prevent media nonparties from further dissemination of proprietary information, business litigants would be incurring costs far beyond those associated with the expenses of trial. ${ }^{111}$ The uncontrolled dissemination of confidential information by a nonparty threatens not only true trade secrets on which businesses already rely, ${ }^{112}$ but also the development of proprietary information. In Kewanee Oil Co. v. Bicron Corp. ${ }^{113}$ the Supreme Court noted the importance of confidentiality to research and development of ideas even though the discovery itself may not be patentable. ${ }^{114}$ The Court posited that the absence of confidentiality in research and development would ultimately undermine the

986, 1003-04 (1984) (arguing that trade secrets constitute property for purposes of the Takings Clause of the Fifth Amendment).

${ }^{103}$ See Gelfand, supra note 105 , at 718.

${ }^{109}$ See id.

${ }_{10}$ See POOLEY, supra note 103, at xiii ("Since businesses have relatively equal access to the raw materials of commerce, their success depends on their abilities to protect and exploit their technology and other proprietary data.").

111 See id. at xii (noting that "[t] he damage to American business from theft of trade secrets is estimated to exceed $\$ 4$ billion annually").

112 For instance, the noteworthy trade secret litigation involving the Coca-Cola Company revolved around a dispute over the formula for the drink, which the Delaware court acknowledged was "one of the best-kept trade secrets in the world." Coca-Cola Bottling Co. v. Coca-Cola Co., 107 F.R.D. 288, 289 (D. Del. 1985). The court expressed concern about protecting the secret formula from disclosure outside the direct litigation process. See id. at 294.

113416 U.S. 470 (1974).

${ }^{114}$ See id. at 485. 
most efficient methods of technological innovation. ${ }^{115}$ Furthermore, litigants always face the risk that competitors are filing lawsuits primarily to gain access to confidential proprietary information. ${ }^{116}$ In such a scenario, it is immaterial whether the business filing the suit desires the information for itself or whether it simply wants to injure the competitor through public release of the information. ${ }^{117}$ From the perspective of the litigant seeking protection, release of the protected information would be invidious regardless of whether it was disseminated by the opposing litigant or a nonparty.

The property interests of a litigant, along with the litigant's privacy concerns and the court's efficiency needs, provide a glimpse of the interests possibly implicated by failing to prevent protective orders from being enforced against nonparties which have acquired, legally or illegally, confidential information. The interests implicated suggest that protective orders should be extended to prevent nonparty dissemination. Nonetheless, it does not necessarily follow that legal precedent provides lower courts with the power to enforce such orders against nonparties. ${ }^{118}$ Rhinehart was limited to the proposition that protective orders could withstand a First Amendment challenge in their enforcement against parties to the litigation. ${ }^{119}$ Lower courts must therefore search beyond Rhinehart for legal authority to justify enforcing a protective order against nonparties. limited:

115 See $i d$. at 486 . The Court eloquently stated that if trade secret protection were

The innovative entrepreneur with limited resources would tend to confine his research efforts to himself and those few he felt he could trust without the ultimate assurance of legal protection against breaches of confidence. As a result, organized scientific and technological research could become fragmented, and society, as a whole, would suffer.

Id.

116 See Miller, supra note 11 , at 471.

${ }^{117}$ See e.g., Litton Indus., Inc. v. Chesapeake \& Ohio Ry. Co., 129 F.R.D. 528, 531 (E.D. Wis. 1990) (denying the discovery of certain documents that would provide an advantage to the litigant's competitors and harm its customer relations).

118 See supra Part I.B.

119 See Seattle Times Co. v. Rhinehart, 467 U.S. 20, 34 (1984) ("[J]udicial limitations on a party's ability to disseminate information discovered in advance of trial implicates the First Amendment rights of the restricted party to a far lesser extent than would restraints on dissemination of information in a different context." (emphasis added)). 


\section{Legal JUSTIFICATION FOR PROTEcTing \\ CONFIDENTIAI INFORMATION FROM NONPARTY DISCLOSURE}

Though the Supreme Court has made it clear that protective orders prohibiting dissemination by parties in litigation are "unique" in their relation to the First Amendment, ${ }^{120}$ it is not clear that the First Amendment will permit protective orders to bar nonparties from publication. ${ }^{121}$ Indeed, in Bridges $v$. Califormia, ${ }^{122}$ the Supreme Court imposed stringent limitations on a trial judge's capacity to regulate the out-of-court speech of nonparties. ${ }^{123}$ If dissemination of protective-order material by a nonparty is regarded as "speech," then the legal justification for protective-order enforcement against nonparties must contend with the First Amendment.

${ }^{120}$ See id.

121 See Brief of Appellant The McGraw-Hill Cos., supra note 56, at 29 ("Thus, the Supreme Court's holding [in Rhinehart] goes only to the question of access, and does not address the wholly unrelated question ... of the right of a non-party-including the media-to publish information which is already in its possession.").

122314 U.S. 252 (1941).

123 See id. at 268 ("History affords no support for the contention that the criteria applicable under the Constitution to other types of utterances are not applicable, in contempt proceedings, to out-of-court publications pertaining to a pending case."). Note that the particular out-of-court speech disputed in Bridges involved editorials commenting upon cases pending in state court. Id. at 258, 271. It does not answer the question discussed in this Comment involving the nonparty dissemination of material directly obtained from a protective order.

In Landmark Communications, Inc. v. Virginia, 435 U.S. 829 (1978), the Supreme Court addressed an issue more analogous to the publication of material obtained from confidential proceedings. In Landmark, the Court suggested that while the State may control access to certain confidential proceedings, the First Amendment may prohibit barring the publication of information obtained from those proceedings. See $i d$. at 837-38.

Landmark, however, is distinguishable for a number of reasons. The Court emphasized that a "major purpose" of the First Amendment is "to protect the free discussion of governmental affairs." Id. at 838 (quoting Mills v. Alabama, 384 U.S. 214, 218 (1966)). Protective orders in the civil-discovery context, however, infrequently involve "governmental affairs," but rather involve the business concerns of private litigants. See Richard B. Schmitt, Critics Say Courts Seal Too Much Data, WALL ST. J., Oct. 4, 1995, at B1 ("More business information is being kept from the public under court seal ....").

Furthermore, the Court noted that the confidential judicial review proceedings were "a matter of public interest, necessarily engaging the attention of the news media." Landmark, 435 U.S. at 839. It is debatable, however, whether information sealed under a protective order is a matter of "public interest." See supra notes 97-101 and accompanying text. 


\section{A. Confidential Discovery Materials and the Property-Versus-Speech Debate}

Underlying the First Amendment prior restraint cases ${ }^{124}$ is the notion that the expression and communication of ideas should not be suppressed. ${ }^{125}$ Therefore, any injunction against a media nonparty from disseminating protective-order material "bear[s] a heavy presumption against its constitutional validity."126 Where free speech concerns collide with private property interests in information, however, the Supreme Court has attempted to carve out protection consistent with the First Amendment for legitimate property interests. ${ }^{127}$ Property interests in confidential discovery materials, therefore, form the basis for extending protective-order enforcement to media nonlitigants.

\section{Restraints Based upon Copyright Protection}

In New York Times Co. $v$. United States, ${ }^{128}$ a seminal First Amendment case holding that an injunction prohibiting the newspaper from publishing a classified government study on the Vietnam War was an unconstitutional prior restraint, two concurring opinions acknowledged the unique role of copyright protection in relation to the First Amendment. ${ }^{129}$ In particular, Justice White noted that Article 1, Section 8 of the Constitution authorizes Congress to secure the "exclusive right" of authors to their writings, "and no one denies that a newspaper can properly be enjoined from publishing the copyrighted works of another."130 Justice White distinguished injunctions under the copyright laws from other prior restraints by noting that these situations are based on the complaint of a private copyright holder enforcing her statutorily enforced private right. ${ }^{131}$ Injunc-

${ }^{124}$ See supra Part I.B.

125 See First Nat'l Bank of Boston v. Bellotti, 435 U.S. 765, 785 (1978) ("[P]ower in government to channel the expression of views is unacceptable under the First Amendment.").

${ }^{126}$ Bantam Books, Inc. v. Sullivan, 372 U.S. 58, 70 (1963).

127 See infra Part III.A.3.

${ }^{128} 403$ U.S. 713 (1971) (per curiam).

${ }^{129}$ See New York Times Co., 403 U.S. at 726 n.* (Brennan, J., concurring) ("Similarly, copyright cases have no pertinence here: the Government is not asserting an interest in the particular form of words chosen in the documents, but is seeking to suppress the ideas expressed therein. And the copyright laws, of course, protect only the form of expression and not the ideas expressed."); see also id. at 731 n.1 (White, J., concurring).

${ }^{130} I d$.

${ }^{131}$ See $i d$. Since 1978, all copyright matters have been governed by federal law 
tions based on copyright are therefore presumed not to violate the First Amendment. ${ }^{132}$

Copyright protection is consistent with free speech because it extends only to the particular form in which thoughts or concepts are expressed and not the thoughts or concepts themselves. ${ }^{133}$ Consequently, as long as others express themselves in a different manner, the information and ideas of the copyright holder may be expressed without offending the copyright protection. ${ }^{134}$ Moreover, copyright protection is constitutionally established under Article I, Section 8, which authorizes Congress to secure the exclusive right of authors to their writings. ${ }^{135}$ Copyright protection thus provides a good focal point for examining the force of the proprietary interest in confidential discovery information.

The potential for extending a copyright argument to the exchange of discovery material was explored at the district court level in Honda Research $\mathcal{E}^{\circ}$ Dev. Co. v. Loveall. ${ }^{136}$ Loveall, the plaintiff, originally brought a tort action against Honda in state court for an injury sustained while riding an all-terrain cycle. During discovery, the plaintiff requested information on the design, specifications, testing, developmental techniques and components of the vehicle from the defendant company, Honda. ${ }^{137}$ In response, Honda sought and obtained a protective order to cover competitively

under 17 U.S.C. $\$ \$ 101-810$. Note that under federal copyright law, a copyright owner has the exclusive rights to reproduce the copyrighted work and to distribute copies or derivatives of the copyrighted work to others. See Robert J. Jacobson, Protecting Discovery by Copyright, 71 J. PAT. [\& TRADEMARK] OFF. SOC'Y, 483, 487-88 (1989). To benefit from copyright protection, however, the litigants would have to register confidential material before or upon receiving the protective order. See id.

132 See Diane L. Zimmerman, Information as Speech, Information as Goods: Some Thoughts on Marketplaces and the Bill of Rights, 33 WM. \& MARY L. REV. 665, 666 (1992).

${ }^{139}$ See New York Times, 403 U.S. at 726 n.* (noting that copyright cases were inapplicable since the Government was seeking to suppress the ideas rather than the words chosen to express the ideas).

134 See Zimmerman, supra note 132, at 666 .

195 U.S. CONST. art. 1, $\S 8, \mathrm{cl} .8$ ("Congress shall have [the] Power . . . To promote the Progress of Science and useful Arts, by securing for limited Times to Authors and Inventors the exclusive Right to their respective Writings and Discoveries.").

Because Article 1, Section 8, Clause 8, secures the rights of inventors to their respective discoveries, see $i d$., the Court should encounter little difficulty in distinguishing the constitutional validity of injunctions based on patent protection from those based on copyright protection.

${ }^{136} 687$ F. Supp. 355 (E.D. Tenn. 1985). For an extensive look at this case and a general background on the subject of copyright, see Jacobson, supra note 131.

${ }^{137}$ See Loveall v. American Honda Motor Co., 694 S.W.2d 937, 938-39 (Tenn. 1985). 
sensitive information. ${ }^{138}$ Honda was not satisfied with pretrial protection, however, so it sought further restrictions on the sharing of evidence introduced at trial ${ }^{139}$ by filing a complaint in federal district court seeking injunctive relief pursuant to the federal copyright laws. ${ }^{140}$

Honda exercised its rights as a copyright owner because it had registered the disputed documents as unpublished works under a "special relief" provision made to the United States Register of Copyrights. ${ }^{141}$ The district court agreed with Honda and issued a preliminary injunction-eventually a permanent injunction-enjoining the state court plaintiff's attorneys and others from releasing for publication or inclusion in the public record the copyrighted documents. ${ }^{142}$ In issuing the preliminary injunction, the district court pointed out that Honda, like any copyright owner, "has the exclusive rights to reproduce the copyrighted documents, to prepare derivative works from the copyrighted documents, and to distribute copies of the copyrighted documents to others." 148 Lending substantial support to the district court was the seminal Supreme Court case Harper $\mathcal{E}$ Row Publishers, Inc. v. Nation Enterpris$e s,{ }^{144}$ which held that exclusive copyright protection included the right to control the first public distribution of the copyrighted documents, as well as the choice of whether to make the material public at all. ${ }^{145}$

Crucial to the analysis of the Loveall decision was that the "fair use" defense, a statutory defense to an allegation of copyright infringement, ${ }^{146}$ was inapplicable to Honda's claim of copyright protection. The district court sidestepped the fair use issue, however, by recognizing that it was of little substance when applied to confidential, unpublished works, such as the discovery documents sought in Loveall. ${ }^{147}$ The district court again cited Harper $\mathcal{E}^{\circ}$

\footnotetext{
138 Id. at. 940.

${ }^{139}$ See Jacobson, supra note 131 , at 486 .

${ }^{140}$ See Loveall, 687 F. Supp. at 356.

${ }^{141}$ See id. at 357.

142 See id.

143 Jacobson, supra note 131, at 491.

144471 U.S. 539 (1985).

145 See id. at 555, 564.

${ }^{146}$ See 17 U.S.C. \$ 107 (1994).

${ }^{147}$ See Jacobson, supra note 131, at 492.
} 
Row ${ }^{148}$ which noted that publication of a work is a "critical element" in the fair use defense. ${ }^{149}$

While the Loveall decision supports the idea of providing litigants with additional protection for confidential information exchanged during the discovery process, it also serves as an avenue for extending protective-order enforcement to media nonlitigants. Although Honda was granted a protective order to protect its confidential business information, the protective order lost its force upon the introduction of the information in the trial record. ${ }^{150}$ Faced with the prospect of competitively sensitive information becoming public in the trial record, Honda successfully used federal copyright doctrine to keep the material out of the trial record and out of competitors' hands.

Copyright registration under the special relief provision used by Honda is also available for documents that are neither technical nor highly secret. A special relief request may be granted for mere "confidentiality."151 Provided that litigants, like Honda, take the necessary steps to copyright documents, they should likewise be able to use copyright arguments to protect the use or disclosure of confidential material exchanged during discovery. It follows that if a protective order has been issued that covers copyrighted material, and a media nonlitigant nonetheless obtains the information, a litigant should be able to secure the enforcement of the protective order against the nonlitigant using copyright arguments.

\section{Trade Secret Status and Takings Analysis}

While federal copyright protection has frequently been accepted as consistent with the First Amendment, doctrinal complexities develop when the analysis extends to other forms of intangible property that also implicate free speech. ${ }^{152}$ In Ruckelshaus $v$. Monsanto Co., ${ }^{153}$ the Supreme Court determined that trade secrets constituted "property" for purposes of the Fifth Amendment's

148 See Lovealh, 687 F. Supp. at 359.

149471 U.S. at 564.

${ }^{150}$ See Seattle Times Co. v. Rhinehart, 467 U.S. 20, 37 (1984) (holding that a protective order's validity depended on its being narrowly drawn to "the context of pretrial civil discovery").

131 See Jacobson, supra note 131, at 488 (citing COMPENDIUM II OF COPYRIGHT OFFICES PRACTICES $\$ 808.03$ (a) (1984)).

152 See Zimmerman, supra note 132, at 666-67.

${ }^{153} 467$ U.S. 986 (1984). 
Takings Clause. ${ }^{154}$ The fact that the Court affirmed the proprietary interest in trade secrets was uncontroversial. ${ }^{155}$ To recognize the Fifth Amendment interest in trade secrets, however, acknowledged the judicial role in preventing the state from taking "private property ... for public use without just compensation." 156 Considering that courts are "state actors" for purposes of the Fifth Amendment, ${ }^{157}$ and that the state or federal government uses its coercive power to enforce discovery requests, ${ }^{158}$ a court's failure to adequately enforce a protective order sealing valuable trade secrets arguably initiates a takings analysis. ${ }^{159}$

In Ruckelshaus, the Supreme Court outlined four general steps that are to be followed to determine if a taking has occurred. ${ }^{160}$ First, a court must determine if the item affected is "property." Second, the state actor must have "taken" it. Third, the taking must be for a "public purpose," as takings for a private purpose are constitutionally forbidden. Finally, if a taking has occurred for a public purpose, the owner must have received "just compensation."161

\section{a. Trade Secrets as Property}

As noted above, the Supreme Court unanimously held in Ruckelshaus that trade secrets are property protected by the Fifth Amendment and cannot be taken against an owner's will without just compensation. ${ }^{162}$ In Ruckelshaus, the Court considered the constitutionality of the Environmental Protection Agency's ("EPA") use of information that a company manufacturing agricultural chemical products disclosed to the agency pursuant to a legislative act. In determining that the company had a Fifth Amendment interest in the information disclosed to the EPA, the Court noted that property

${ }^{154}$ See id. at 1003-04.

${ }^{155}$ See Gelfand, supra note 105, at 720 (noting that reported cases treating trade secrets as property "extend back to the late 1700s").

156 U.S. CONST. amend. V.

${ }^{157}$ See Chicago, B. \& Q.R.R. v. Chicago, 166 U.S. 226, 233-35 (1897) (applying the Takings Clause to the Illinois judiciary).

${ }^{153}$ See Trade Secrets in Discovery, supra note 104, at 1337.

159 See Gelfand, supra note 105, at $710 \mathrm{n} .32$ (suggesting that while no taking occurs where trade secrets are exchanged in discovery pursuant to a protective order, "a significant problem remains . . . because courts cannot effectively guarantee that trade secret protective orders will be followed").

${ }^{160}$ See Ruckelshaus v. Monsanto Co., 467 U.S. 986, 1000-01 (1984).

161 See id.

162 See id. at 1003-04. 
interests "'are not created by the Constitution. Rather, they are created and their dimensions are defined by existing rules or understandings that stem from an independent source such as state law."'163 The Court then looked to Missouri law to define a trade secret as "any formula, pattern, device or compilation of information that is used in one's business, and that gives him an opportunity to obtain an advantage over competitors who do not know or use it."164 Other commentators have persuasively argued, however, that state law cannot be the real source of this decision because that would allow a state to be the "final arbiter of the Constitution." 165 Rather, the "independent source" in Ruckelshaus reflected the broad consensus that trade secrets are to be considered property. ${ }^{166}$

Reliance on a broader consensus for the definition of property rights is a judicially recognized practice and was recently affirmed in Carpenter $v$. United States. ${ }^{167}$ In Carpenter, the Court acknowledged a newspaper's property rights in its "confidential business information" which was misappropriated from the newspaper and traded upon by a reporter and stockbroker. ${ }^{168}$ What is remarkable about this holding is that it was not based upon trade secret statutes or restatements, but rather upon the Court's acknowledgement of its own dicta from previous cases. ${ }^{169}$ This provides ample support for the argument that the Ruckelshaus Court relied on the general consensus that trade secrets constitute property, thus allowing the Court to recognize it "as a matter of constitutional judicially created law." The subtle extension to "confidential business information" in Carpenter reflects the exercise of this notion.

The Court noted that the Takings Clause has long been interpreted as construing a broad definition of property not restricted to "its vulgar and untechnical sense of the physical thing with respect to which the citizen exercises rights recognized by

${ }^{169}$ Id. at 1001 (quoting Webb's Fabulous Pharmacies, Inc. v. Beckwith, 449 U.S. 155,161 (1980)).

${ }_{164}$ Id. (relying on the RESTATEMENT (FIRST) OF TORTS $\$ 757$, comment b (1939)).

${ }^{165}$ Gelfand, supra note 105 , at 713 .

${ }^{166}$ See id. at 721 n.76 (listing federal statutes that recognize the proprietary interest in trade secrets). Indeed, the majority of states now follow $\S 757$ of the First Restatement of Torts defining trade secrets, while 16 states have adopted similar wording announced in the Uniform Trade Secrets Act. See id. at 722.

${ }_{167} 484$ U.S. 19 (1987).

${ }^{163}$ Id. at 27-28.

${ }^{169}$ See id. at 26 (citing cases in which the Court apparently has "long" recognized the property interest in "[c]onfidential business information").

${ }_{170}$ Gelfand, supra note 105 , at 712 . 
law." "171 Thus, in affirming the proprietary interest in trade secret information, the Court recognized the general perception, and adopted as its own view, that the intangible nature of trade secrets should not deprive them of the constitutional protection allotted to tangible property. ${ }^{172}$

\section{b. Violation of Protective Orders as "Taking" Property}

To determine whether a "taking" has occurred depends on the degree to which the state actor deprives the owner of his property interest. ${ }^{173}$ While no clear formula determines whether a taking has occurred, "[i]f the property owner loses too many important sticks from his bundle, his property has been taken." 174 Therefore, a taking will almost surely be found where there is a complete appropriation of property such that the owner is unable to gain any benefit from it. ${ }^{175}$

With regard to trade secrets, the Supreme Court in Ruckelshaus noted that the substantive value of the trade secret property interest was determined by the degree to which it was kept confidential. ${ }^{176}$ Therefore, in the context of discovery, disclosure to competitors would generally constitute a taking because it eliminates the competitive advantage associated with the secret and undermines the owner's ability to protect her property interest. ${ }^{177}$ Some have argued that, in theory, carefully crafted protective orders that limit access to trade secrets to opposing litigants, and prevent the dissemination of trade secrets to third parties, will prevent a taking from occurring. ${ }^{178}$ This theory has persuaded some courts, and

${ }^{171}$ Ruckelshaus v. Monsanto Co., 467 U.S. 986, 1003 (1984) (quoting United States v. General Motors Corp., 323 U.S. 373, $377-78$ (1945)).

${ }^{172} \mathrm{See} i d$. (noting that, like trade secrets, "the Court has found other kinds of intangible interests to be property for purposes of the Fifth Amendment's Taking Clause").

${ }^{173}$ See Pennsylvania Coal Co. v. Mahon, 260 U.S. 393, 413 (1922) ("One fact for consideration in determining [limitations on the state's police power] is the extent of the diminution. When it reaches a certain magnitude, in most if not in all cases there must be an exercise of eminent domain and compensation to sustain the act.")

${ }^{174}$ Gelfand, supra note 105, at 725 (quoting Note, Federal Disclosure Statutes and the Fifth Amendment: The New Status of Trade Secrets, 54 U. CHI. L. REV. 334, 342 (1987)).

${ }_{175}$ See Trade Secrets in Discovery, supra note 104, at 1341.

${ }^{176}$ See Ruckelshaus, 467 U.S. at 1002 ("[T] he extent of the property right therein is defined by the extent to which the owner of the secret protects his interest from disclosure to others.").

177 See Trade Secrets in Discovery, supra note 104, at 1342.

178 See Gelfand, supra note 105, at 734. 
they have held that protective orders may obviate the need for a takings analysis. ${ }^{179}$

Protective orders will not prevent unconstitutional takings, however, if they are ineffective. ${ }^{180}$ When a court, under the Federal Rules of Civil Procedure, requires a company to disclose a trade secret to an opposing litigant, the subsequent disclosure of that trade secret to third parties who are not also bound by the protective order would, presumably, result in a taking. As the Court noted in Ruckelshaus, "[i]f an individual discloses his trade secret to others who are under no obligation to protect the confidentiality of the information, or otherwise publicly discloses the secret, his property right is extinguished." ${ }^{181}$ Therefore, although an opposing litigant may be obligated to protect the confidentiality of the trade secret pursuant to the protective order, the subsequent disclosure to a third party who is not so bound would constitute "public disclosure," thus eliminating the proprietary interest in the trade secret and resulting in a taking.

Moreover, the reasoning of Carpenter comports with the theory that a protective-order violation, by any party privy to the information, would cause harm in the form of lost property rights to the trade secret owner. ${ }^{182}$ In upholding the convictions of the reporter and stockbroker who traded, on the newspaper's "confidential business information," the Carpenter Court noted that determinable monetary loss was unnecessary: "[I]t is sufficient that the [party] has been deprived of its right to exclusive use of the information, for exclusivity is an important aspect of confidential business information ...."183 Thus, a litigant who is already at risk when she discloses confidential business information under a protective order, is in further jeopardy when a nonparty acquires and seeks to disseminate the information. ${ }^{184}$

${ }^{179}$ See, e.g., St. Jude Medical, Inc. v. Intermedics, Inc., 107 F.R.D. 398, 401 (D. Minn. 1985) (holding that because "attorneys realize their ethical obligations extend to the overseeing of appropriate security measures" a protective order will effectively prevent disclosure of trade secrets).

${ }^{180}$ Cf. Trade Secrets in Discovery, supra note 104, at 1342 ("Discovery of trade secrets in the absence of disclosure to third parties, however, would not be a taking if the court crafted a protective order to preserve a significant portion of the owner's rights." (emphasis added)).

${ }^{181}$ Ruckelshaus v. Monsanto Co., 467 U.S. 986,1002 (1984).

${ }^{182}$ See Trade Secrets in Discovery, supra note 104, at 1343-44 (noting that California enacted legislation recognizing the property interests of trade secret owners whose secrets were exposed at trial).

${ }^{183}$ Carpenter v. United States, 484 U.S. 19, 26-27 (1987).

${ }^{184}$ It is important to note that confidential business information does not lose its 


\section{c. The Public Use Requirement}

Once a court determines that a taking has occurred, it will constitutionally validate the taking only if it serves a public purpose and the owner receives "just compensation." 185 Trade secrets disclosed pursuant to a protective order and subsequently obtained by a media nonlitigant would seem to constitute private use in violation of this requirement. In practice, however, it would be very difficult to persuade a court that the public use requirement has not been met. While the primary beneficiary of the violation of the protective order may theoretically be the media nonlitigant, the courts have generally held that even an attenuated benefit to the public may be enough to constitute a "public purpose." 186 Therefore, even the existence of a slightly probative "public interest" in the disputed discovery material would probably fulfill the public use requirement for constitutional jurisprudence. ${ }^{187}$

\section{d. The Failure of Just Compensation and the Need for Alternative} Remedies

Just compensation requires that if a taking does occur, as in the case where a protective order fails to prevent disclosure to a media nonlitigant, the owner should receive the market value of the property. ${ }^{188}$ The compensation provision raises several derivative issues, however, when a protective order fails to protect trade secrets. First, in the event of unconsented disclosure to a media nonlitigant, who should be responsible for payment to the trade secret owner? Because the "taking" occurs at the initial stage when the state actor coerces the process of discovery, the court should be primarily

property status when it is acquired by a media nonparty to a litigation, as long as the party seeking the property status did not disclose the information. See 1 R. MILGRIM, TRADE SECRETS $\$ 1.01$ [2] (1983). Milgrim notes that trade secrets only lose their status as "secrets" if they are disclosed to one who is under no obligation to protect the confidences of the information. See id. If the media nonparty acquires the information from the opposing party, or acquires it through its own illegitimate means, then trade secret status still applies.

185 Ruckelshaus, 467 U.S. at 1001.

${ }^{186}$ See, e.g., Poletown Neighborhood Council v. City of Detroit, 304 N.W.2d 455, 458 (Mich. 1981) (allowing the State of Michigan to condemn an entire neighborhood so that General Motors could build a new factory and finding a public purpose in the economic benefits to the public).

${ }^{187}$ See supra notes $97-101$ and accompanying text.

${ }^{188}$ See United States v. 50 Acres of Land, 469 U.S. 24, 29 (1984) (noting that just compensation is normally measured by the market value at the time of the taking). 
responsible for compensation. However, since courts neither possess the funds nor the willingness to pay for a taking, most commentators suggest that judicial takings must be invalidated outright. ${ }^{189}$ These commentators suggest that once it is established that disclosure of trade secrets will occur in discovery, the court could avoid a taking by denying discovery altogether or by using protective orders. ${ }^{190}$ The use of protective orders to prevent a Fifth Amendment violation, however, provides little solace to the litigant who relied on an order which failed to prevent third-party disclosure.

One alternative would be to have the party who disclosed the information to the media nonlitigant compensate for the violation. There are several problems with this option. If a party violated an order and disclosed a trade secret, proof of that violation would frequently be difficult to establish. ${ }^{191}$ Furthermore, a media nonlitigant may obtain protective-order information with neither party's assistance. Rather, the information may be acquired directly from the court itself. ${ }^{192}$

Moreover, requiring compensation from the party who was responsible for disseminating the protected material creates a more perplexing issue: it assumes that "just compensation" can be fairly determined. Trade secrets are ambiguous by nature. ${ }^{193}$ Some litigants will have proprietary interests in commercial data which they have yet to quantify. ${ }^{194}$ Furthermore, some proprietary information, such as the "confidential business information" of Carpenter, 1343.

${ }^{189}$ See Gelfand, supra note 105, at 731; Trade Secrets in Discovery, supra note 104, at

${ }^{190}$ See Gelfand, supra note 105, at 732 (suggesting that reading Rule 26 as requiring protective orders when trade secrets are involved in discovery, as opposed to making it a discretionary power, could be a viable alternative).

191 For instance, media nonparties will rarely be willing to compromise their confidential sources. See Claudia MacLachlan, Did Business Week Fold Too Easily?, NAT'L L.J., Oct. 23, 1995, at Al, A21 ("If a journalist makes a promise to a source, you don't break it, period." (quoting Jane E. Kirtley, Executive Director of the Reporters Committee for Freedom of the Press)).

In the Business Week case, for example, a Business Week journalist was unwilling to directly name the source of the confidential discovery documents but apparently provided enough clues to reveal the source's identity. See id.

192 This situation could arise either when a court clerk accidentally disseminates the protected information to a media nonlitigant, when a media nonlitigant obtains the information under false pretenses, or when the information is simply mailed to the wrong address.

${ }^{193}$ See Marcus, supra note 54, at 490 (noting the "elasticity of the definition of a trade secret").

${ }^{194}$ See POOLEY, supra note 103, at 7-8 (pointing out ways in which companies can go about identifying their proprietary information). 
cannot be fairly evaluated in monetary terms, but rather must be identified in terms of its "exclusive use."195 More importantly, some trade secrets, although clearly identifiable, could never be adequately replaced through a compensation remedy. ${ }^{196}$

The Fifth Amendment Takings Clause in the context of trade secrets demonstrates how property rules will inevitably conflict with First Amendment concerns when protective-order information is acquired by a media nonlitigant. Because the Court has endorsed the use of injunctions to protect such intangible property rights, ${ }^{197}$ this remedy should not be disregarded simply because the party affected is a media nonlitigant. In fact, allowing the use of injunctions as an alternative remedy would strengthen the enforcement power of a protective order, further protect trade secret owners' legitimate property interests, and thereby deter other unconstitutional takings from occurring.

\section{Balancing Property Interests with First Amendment Concerns}

It is arguable that the property interest in the information covered by a protective order demands that the regulation of such material be held to a different standard than that to which other forms of expression are held. Two Supreme Court cases that directly confront the property-versus-First Amendment issue illustrate this notion. In San Francisco Arts $\mathcal{E}^{\mathcal{O}}$ Athletics, Inc. v. United States Olympic Committee ("SFAA"), ${ }^{198}$ the Supreme Court confronted a challenge to Congressional legislation that granted the United States Olympic Committee ("USOC") the right to prohibit certain commercial and promotional uses of the word "Olympic" and various Olympic symbols. ${ }^{199}$ The petitioner, San Francisco Arts \& Athletics, Inc.,

${ }^{195}$ Carpenter v. United States, 484 U.S. 19, $26-27$ (1987) (arguing that "exclusivity is an important aspect of confidential business information and most private property for that matter").

${ }^{196}$ See Gelfand, supra note 105 , at $734 \mathrm{n} .117$ (arguing that "no remedy could ever replace the exclusivity that now exists with regard to, for example, the formula for Coca-Cola").

${ }^{197}$ See, e.g., Carpenter, 484 U.S. at 26 (arguing that where a corporation has the exclusive property right to its confidential business information, a court of equity "'will protect [the property interest] through the injunctive process or other appropriate remedy" (quoting 3 LENORE M. ZAJDEL, FLETCHER CYCLOPEDIA OF THE LAW OF PRIVATE CORPORATIONS $\$ 857.1$ (rev. vol. 1986))).

${ }^{198} 483$ U.S. 522 (1987).

${ }^{199}$ See id. at 526-28. The challenged legislation was $\S 110$ of the Amateur Sports Act, 36 U.S.C. $\$ 380$ (1994). See San Francisco Arts $\mathcal{E}$ Athletics, 483 U.S. at 526. 
challenged the USOC's property right in the word and symbols, in part on its inconsistency with the First Amendment. ${ }^{200}$

In upholding the statute and the property interest, the Court acknowledged that the risk of suppressing ideas "always has been balanced against the principle that when a word acquires value 'as the result of organization and the expenditure of labor, skill, and money' by an entity, that entity constitutionally may obtain a limited property right in the word." ${ }^{201}$ The Court in SFAA clearly engaged in this balancing, opening its analysis with a discussion of the desirability of trademark protection "because trademarks foster competition and the maintenance of quality by securing to the producer the benefits of good reputation." ${ }^{202}$ While the Court's holding in SFAA reinforces the Lanham Act, ${ }^{203}$ which defines trademark protection, it also demonstrates the Court's interest in protecting proprietary interests from inappropriate infringement. In Zacchini v. Scripps-Howard Broadcasting Co., ${ }^{204}$ the Court addressed a claim of damages by a performer whose act-being shot from a cannon as a "human cannonball"-was recorded on film and broadcast on a news program. While the claimed proprietary interest was a common law "right of publicity," 205 the Court, in upholding the performer's claim, found support in the fact that the interest was "closely analogous to the goals of patent and copyright law."206 Protecting the interest, therefore, had " a decidedly beneficial effect on society." 207 The Court was unpersuaded by arguments that the First Amendment would excuse this property right infringement on grounds of public entertainment and newsworthiness. ${ }^{208}$

200 See id. at 527-28.

${ }^{201}$ Id. at 532 (quoting International News Serv. v. Associated Press, 248 U.S. 215, 239 (1918)).

${ }^{202}$ Id. at 531 (quoting Park 'N Fly, Inc. v. Dollar Park \& Fly, Inc., 469 U.S. 189, 198 (1985)).

203 I5 U.S.C. § 1051 (1994).

204433 U.S. 562 (1977).

205 Id. at 575.

${ }^{206} \mathrm{Id}$. at 573 . Thus, the focus was on "the right of the individual to reap the reward of his endeavors and [had] little to do with protecting feelings or reputation." Id.

207 Id. at 578 n.13 (quoting Kewanee Oil Co. v. Bicron Corp., 416 U.S. 470, 485 (1974)). The Supreme Court has noted that the economic philosophy behind the constitutional clause empowering Congress to grant patents and copyrights is "the conviction that encouragement of individual effort by personal gain is the best way to advance public welfare through the talents of authors and inventors." Mazer v. Stein, 347 U.S. 201, 219 (1954).

${ }^{208}$ See Zacchini, 433 U.S. at 578. 
Zacchinisupports the proposition that certain intangible property interests, such as the right to confidential business information, deserve protection even in the face of First Amendment interests. ${ }^{209}$ The theory that information covered by a protective order will affect property interests is thus crucial to the argument that protective orders should be legally enforceable against media nonlitigants who have acquired sealed information. The Supreme Court has acknowledged the predominance of a "limited property right" once that right has been established: ${ }^{210}$ where a corporation has the exclusive property right to its confidential business information, a lower court "will protect [the property interest] through the injunctive process or other appropriate remedy." 211 Establishing a private property interest in protective-order material, therefore, lessens the significance of a First Amendment challenge.

\section{B. Enforcing Protective Orders Against Nonparties Through the Injunctive Powers of the Courts}

Even if the First Amendment does not provide an obstacle to an injunction against a media nonparty who had acquired access to confidential discovery materials, the court may still have to determine whether it has authority to enforce its orders by injunction against nonparties to the litigation. ${ }^{212}$ Rule $26(\mathrm{c})(7)$ fails to provide

${ }^{209}$ Perhaps significantly, the Zacchini Court pointed out that the claimant sought damages for the broadcast of his "act" without his consent, rather than seeking an injunction prior to the broadcast itself. See Zacchini, 433 U.S. at 578 ("[N]either the public nor [the news program] will be deprived of the benefit of petitioner's performance as long as his commercial 'stake in his act is appropriately recognized. Petitioner does not seek to enjoin the broadcast of his performance; he simply wants to be paid for it."). Lower courts, however, have subsequently cited Zacchini as approval of the "right of publicity," while simultaneously granting injunctive relief to protect this property interest. See, e.g., Martin Luther King, Jr., Ctr. for Social Change, Inc. v. American Heritage Prods., Inc., 694 F.2d 674, 679-80 (11th Cir. 1983) (reversing denial of injunction for violation of Martin Luther King, Jr.'s right of publicity); Bi-Rite Enters., Inc. v. Bruce Miner Co., 757 F.2d 440, 442, 444 (1st Cir. 1985) (affirming lower court's choice of law in granting injunctive relief to prevent distribution of posters depicting certain popular music performers).

${ }^{210}$ See Carpenter v. United States, 484 U.S. 19, $27-28$ (1987) (acknowledging a newspaper's rights in its "confidential business information"); Ruckelshaus v. Monsanto Co., 467 U.S. 986, 1003 (1984) (holding that trade secrets are considered property for purposes of the Fifth Amendment Takings clause); $c f$. Zimmerman, supra note 132, at 724 (" $[J]$ udges have sometimes found in the flexibility offered by the term "property" a congenial opportunity to do what the First Amendment forbidscensor, or at least harry, speech they find offensive, unfair, or unworthy.").

211 Carpenter, 484 U.S. at 26 (quoting 3 LENORE M. ZAJDEL, FLETCHER CYCLOPEDIA OF THE LAW OF PRIVATE CORPORATIONS $\$ 857.1$ (rev. vol. 1986)).

212 See Brief of Appellant The McGraw-Hill Cos., supra note 56, at 37-38. 
guidance on the issues of who is bound by a protective order and what penalties should apply in the event of its violation. ${ }^{213}$ At least one court has found that regardless of whether the protective order contained statements specifically binding the nonparty to the protective order, ${ }^{214}$ the court may punish the nonparty violator of the protective order under its injunctive powers. ${ }^{215}$ More importantly, if a court wishes to prevent or restrain dissemination of courtprotected confidential information that is already in the hands of a media nonparty, an injunction is the appropriate tool. ${ }^{216}$ Therefore, the scope of a court's injunctive powers must be analyzed with regard to a media nonparty.

\section{Scope of Injunctive Power Under Rule 65(d)}

While the early development of the law of injunctions bound only the parties to the suit, courts recognized that binding only those present in court would inadequately protect the interests of those who had secured the injunction. ${ }^{217}$ The law thus developed to bind nonparties to the extent that the nonparty's act was tantamount to an act of a party. ${ }^{218}$ Judge Learned Hand defined this development when he argued that where "a person ... knowingly assists a defendant in violating an injunction [that person] subjects himself

Significantly, given the property status of confidential business information asserted in Carpenter, a litigant may have a private claim against the media nonparty who has acquired the information in spite of the protective order. This inquiry, however, is beyond the scope of this Comment.

${ }^{213}$ See FED. R. CIV. P. 26(c) (7); see also Nancy L. Krzton, Note, Due Process Concerns in Discovery: Who May Protective Orders Bind?, 44 U. PITT. L. REV. 1081, 1083 (1983).

${ }^{214}$ See Krzton, supra note 213, at 1083.

${ }^{215}$ See Quinter v. Volkswagen of Am., 676 F.2d 969, 972 (1982) (observing that the nonparty "need not be expressly named in the Protective Order in order to be held liable for civil contempt").

${ }^{216}$ See Procter \& Gamble Co. v. Bankers Trust Co., 900 F. Supp. 186, 192 (S.D. Ohio 1995) (discussing the test that must be met in order for an injunction to be a proper remedy).

${ }^{217}$ See Hutcheson v. Iowa Dist. Ct., 480 N.W.2d 260, 263 (Iowa 1992) (noting that upholding an injunction against a nonparty was a "logical extension" of the law as it evolved during some of the "turn-of-the-century cases"); State v. Terry, 168 P. 513, 515 (Wash. 1917) ("Though appellant was not a party to the decree and was never served with a copy of it, her actual knowledge of the injunction renders her liable to punishment for contempt in violating it."); see also Note, Binding Nonparties to Injunction Decrees, 49 MINN. L. REV. 719, 719 (1965).

${ }^{213}$ See Alemite Mfg. Corp. v. Staff, 42 F.2d 832, 833 (2d Cir. 1930) ("[T] he only occasion when a person not a party may be punished, is when he has helped to bring about, not merely what the decree has forbidden, because it may have gone too far, but what it has power to forbid, an act of a party."). 
to civil as well as criminal proceedings for contempt." ${ }^{219}$ Though this expansion of the law of injunctions appears quite straightforward, it has become difficult to apply in practice. ${ }^{20}$ Using phrases such as "independent interest" or "independent activity" to define when a nonparty does not violate an injunction, ${ }^{221}$ the clarity in injunctive law has suffered under the usage of its various terms. ${ }^{222}$

Despite the malleability of the terms guiding injunctive law, a good starting point for an examination of the boundaries of a federal court's injunctive power is Federal Rule of Civil Procedure 65(d) ("Rule 65(d)"). ${ }^{223}$ Rule 65(d) states in relevant part: "Every order granting an injunction and every restraining order ... is binding only upon the parties to the action, their officers, agents, servants, employees and attorneys, and upon those persons in active concert or participation with them who receive actual notice of the order by personal service or otherwise." ${ }^{224}$ Rule 65 (d) has thus been interpreted to incorporate the underlying policy that the order cannot be "so broad as to make punishable the conduct of persons who act independently and whose rights have not been adjudged according to law."'225

Applying the policy of Rule 65(d) to protective orders and media nonparties possessing court-protected confidential information poses two issues: 1) does "acting independently" implicate the method used by the media nonparty to acquire the information; and 2) does it take into account when the media nonparty had knowledge of the protective order? The method used to acquire the confidential

219 Id. at 832.

${ }_{220}$ See Doug Rendleman, Beyond Contempt: Obligors to Injunctions, 53 TEX. L. REV. $873,878-79$ (1975) (noting that the law regarding persons bound by injunctions has been littered with ambiguous terms and is difficult to apply).

${ }^{221}$ See, e.g., Regal Knitwear Co. v. NLRB, 324 U.S. 9, 13 (1945) (disallowing injunctions which punish the conduct of persons "who act independently and whose rights have not been adjudged according to law"); see also Rendleman, supra note 220 , at 880 .

${ }^{222}$ See Rendleman, supra note 220 , at 878-79.

${ }^{223}$ See Golden State Bottling Co. v. NLRB, 414 U.S. 168, 179 (1973) (discussing Rule 65(d) injunctions generally); Regal Knitwear Co., 324 U.S. at 14 (discussing Rule 65 (d) injunctions as analogous to an NLRB cease-and-desist order).

${ }^{224}$ FED. R. CIV. P. 65(d). "Actual notice" of the injunction is a prerequisite to binding both "those persons in active concert or participation with them." Id. The alleged violator of the injunction, however, need not have been served if the "knowledge" came from another source, such as word of mouth, newspaper, or other forms of notice. See Binding Nonparties to Injunction Decrees, supra note 217, at 720.

${ }_{225}$ Golden State Bottling Co., 414 U.S. at 180 (quoting Regal Knitwear Co., 324 U.S. at 13) (emphasis added). 
information must be given proper weight in order to enjoin, for example, the media nonparty who purchases the court-protected information from a litigant or the courthouse itself. ${ }^{226}$ Moreover, assessing injunctive power based upon actual knowledge of the protective order must vary temporally in order to protect the due process rights of the media nonparty who gathers information and only later is apprised of its protected status. While neither of these issues will definitively answer whether the media nonparty acted "independently" for purposes of injunctive law, they do delineate a center of focus: whether the nonparty was acting "independently" when the confidential information was acquired.

Considering the manner in which the information is acquired is consistent with several Supreme Court opinions. In those cases, which involved prior restraints, the Court suggested that the level of First Amendment protection afforded to the media may depend on how the information was obtained. ${ }^{227}$ More significantly, focusing

${ }^{226}$ These methods implicate other legal consequences, such as judicial discipline or penalties for bribery.

${ }_{227}$ Although the Court has not settled the issue of whether a newspaper that uses unlawful means to acquire information may be punished prior to publication of that information, several opinions suggest this proposition. See Nebraska Press Ass'n v. Stuart, 427 U.S. 539, 617 (Stevens, J., concurring) (reserving judgment on "[w] hether the same absolute [First Amendment] protection would apply no matter how shabby or illegal the means by which the information is obtained"); see also McGraw-Hill Cos. v. Procter \& Gamble Co., I16 S. Ct. 6, 7 (1995) (mem.) (noting that "the manner in which [a news magazine] came into possession of the information it seeks to publish may have a bearing on its right to do so"). Several Court opinions, however, expressly reserve judgment on the issue. See, e.g., Florida Star v. B.J.F., 491 U.S. 524, 534 n. 8 (1989) ("The Daily Mail principle does not settle the issue whether, in cases where information has been acquired unlawfully by a newspaper or by a source, government may ever punish not only the unlawful acquisition, but the ensuing publication as well."); CBS Inc. v. Davis, 114 S. Ct. 912, 914 (1994) (suggesting that it is undecided whether "criminal activity by the broadcaster could justify an exception to the prior restraint doctrine under some circumstances"); Landmark Communications, Inc. v. Virginia, 435 U.S. 829, 837 (1978) ("We are not here concerned with the possible applicability of the statute to one who secures the information by illegal means and thereafter divulges it.").

One First Amendment expert has even noted that some members of the Supreme Court may be swayed if a media party misappropriated or bought the information, and that if the information was literally stolen, "it would be problematic." MacLachlan, supra note 191, at A21.

But see New York Times Co. v. United States, 403 U.S. 713 (1971), where it was apparently contested that the confidential documents were "feloniously acquired" from the Pentagon, yet the majority of the Court said the prior restraint could not be upheld. See id. at 714; see also CBS Inc., 114 S. Ct. at 914 ("Nor is the prior restraint doctrine inapplicable because the videotape was obtained through the "calculated misdeeds' of CBS. . . . Subsequent civil or criminal proceedings, rather than prior 
on how the information was acquired with respect to the parties to the litigation would logically comport with the ruling under Rhinehart, which upheld a protective order "[w] here . . [it] ... does not restrict the dissemination of the information if gained from other sources."28 Rhinehart thus suggests that acting "independently" is akin to acquiring information identical to that in the protective order from sources not connected to the litigation. ${ }^{229}$ Therefore, a court would be able to enjoin a media nonparty from acquiring confidential material directly from the court. ${ }^{230}$ The result is less clear if the media nonparty acquires the information from one of the litigating parties in defiance of the protective order.

The Supreme Court provided guidance in Regal Knitwear Co. $v$. $N L R B,{ }^{231}$ where it further delineated the scope of a court's injunctive power under Rule 65(d). In Regal Knitwear Co., the Court noted that a court's power to issue an injunction binds not only the defendants, but also those either identified with them in interest, in "privity" with them, represented by them or subject to their control. ${ }^{232}$ In essence the Court held that defendants may not nullify a decree by carrying out prohibited acts through aiders and abettors, although the latter were not parties to the original proceeding.

Accordingly, for a media nonparty to be legally bound by a protective order under the court's injunctive powers, one of two criteria must be met: the nonparty must either be legally "identified" with a party to the order, or must "aid and abet"233 a party to the order. ${ }^{234}$

restraints, ordinarily are the appropriate sanction for calculated defamation or other misdeeds in the First Amendment context."). In New York Times, however, the documents were not alleged to have been stolen by the media party itself but had been acquired by a third party and then turned over to the media.

${ }^{228}$ Seattle Times Co. v. Rhinehart, 467 U.S. 20, 37 (1984).

${ }^{229}$ See Marcus, supra note 54, at 460 (noting that Rhinehart did not limit the newspaper-party's right to publish material gained "outside of the discovery process," but that this was little consolation "because it might be very difficult to prove that they had obtained information entirely independently of the discovery process").

${ }^{230}$ See Krzton, supra note 213, at 1092-93 ("Where a judicial determination has been made to compel the release of a trade secret under carefully circumscribed conditions, a nonparty who derives access to the trade secret through the courts cannot and should not escape the court's restrictions on use of the information.").

231324 U.S. 9 (1945); see also Krzton, supra note 213, at 1086 (discussing the Regal Knitwear Co. case).

232324 U.S. at 14.

${ }^{239}$ The purpose of the "aid and abet" criteria is to distinguish between an individual who colludes with a party for the purpose of violating an injunction and an individual who acts independently of a party bound by such an order. See infra Part III.B.3.

${ }^{234}$ See Quinter v. Volkswagen of America, 676 F.2d 969, 973 (3d Gir. 1982) 


\section{The "Legal Identity" Test}

In Quinter v. Volkswagen of America, ${ }^{235}$ the Third Circuit applied its version of the "legal identity" test with respect to an expert witness who was not a party to the lawsuit. The case arose out of a lawsuit brought by plaintiff Quinter who sustained injuries in an automobile accident involving a Volkswagen Beetle. During the discovery phase, the district court granted Volkswagen's motion for a protective order to seal certain materials Volkswagen considered trade secrets. ${ }^{236}$ The materials covered by the protective order included a computerized index list of various crash tests performed by Volkswagen on its automobiles. ${ }^{237}$ The expert, who had been retained by the plaintiff, had access to the documents through the plaintiff and thereafter distributed the materials to an outside lawyer who had hired the expert as a consultant in an unrelated case against Volkswagen. ${ }^{238}$ Although the expert was not named in the protective order, the court held that the Regal Knitwear requirements ${ }^{239}$ were fulfilled, and that the expert was thus liable for contempt-the expert had actual knowledge of the protective order and, through his agency relationship with the plaintiff, was legally "identified" as a party. ${ }^{240}$

The agency relationship of Quinter is not so easily transferred to the situation where a media nonparty obtains information from one of the litigants. By definition, an agent acts at the behest and for the benefit of the principal, ${ }^{241}$ and therefore her interests in the merits of the injunction are a function of the interests of the principal. ${ }^{242}$ It is arguable that there are situations where the media nonparty does act "at the behest and for the benefit of the principal." For instance, one member of a prominent law firm recently divulged that he used calculated "leaks" to the press in order to publicize allegations which would advance his client's cause. ${ }^{243}$ This link is attenu-

(reviewing the "thorough and exhaustive analysis of the case" in Thompson $v$. Johnson, 410 F. Supp. 633 (E.D. Pa. 1976)).

${ }^{235} 676$ F.2d 969 (3d Cir. 1982).

256 See id. at 971.

${ }^{237}$ See id.

${ }^{23 s}$ See id. at 972.

${ }^{239}$ See supra note 231 and accompanying text.

240 See Quinter, 676 F.2d at 972.

241 See BLACK's LAW DicTIONARY 63 (6th ed. 1990).

${ }^{242}$ See Binding Nonparties to Injunction Decrees, supra note 217 , at 721.

${ }^{243}$ See Geyelin, supra note 5, at A6 (describing how a prominent litigator utilized a "strategy ... to encourage reporters to publicize the allegations"). 
ated, however, primarily because the media indisputably has its own financial interest in publishing newsworthy information.

It is important to note that the Quinter protective order explicitly released certain Volkswagen trade secrets to the plaintiff on the condition that the use of the information would be confined to the Quinter lawsuit. ${ }^{24}$ One commentator has thus argued that underlying Quinter is the fact that the expert derived any interest he had in the confidential discovery materials solely through the plaintiff. ${ }^{245}$ This "independent interest" analysis is consistent with the Supreme Court's reading of Rule $65(\mathrm{~d})$ in Golden State Bottling Co. $v$. $N L R B .{ }^{246}$ There, the Court held that a purchaser-"successor" of a new business was "in privity" with the prior employer and thus bound by the employer's outstanding unfair labor practice claims because of the purchaser's knowledge of the claims at the time of purchase. ${ }^{247}$ Significantly, the Court reasoned that its holding did not undermine the policy underlying $65(\mathrm{~d})$ because a "tie" could be established between the former employer and the purchaser which established "the requisite relationship of dependence." 248

In the context of a media nonparty who obtains the information from a litigant, one could argue that the nonparty has established its own state of "dependence" on the litigant, and that its rights in the confidential materials likewise have "derived" from those of the litigant. Therefore, since the litigant's rights to the information exchanged in discovery are subject to a court's discretion, ${ }^{249}$ a media nonparty's rights are likewise circumscribed. Moreover, Golden State Bottling Co. suggests that the purchaser's awareness of the outstanding unfair labor practice claims at the time of purchase was significant to establish the "privity" connection. ${ }^{250}$ The potential

${ }^{244}$ The district court entered a protective order on January 23,1979 , which read in pertinent part:

[I] tems obtained by plaintiff or his counsel pursuant to discovery in this case are protected, and neither plaintiff nor his counsel shall themselves copy or permit others to copy said items or otherwise use them for any purpose other than that directly and reasonably related to the above-captioned case.

Quinter, 676 F.2d at 971.

${ }^{245}$ See Krzton, supra note 213, at 1092.

246414 U.S. 168 (1973).

247 See id. at 180 .

248 Id.

249 See Post, supra note 48, at 194 ("[T] he rules of civil procedure do not give litigants 'rights' to information that must be adjudicated before a neutral and umpireal judge, but rather create a system of information exchange to be actively managed by a judge .....").

${ }^{250}$ See Golden State Bottling Co., 414 U.S. at 180 (holding that "a bona fide purchaser 
for an injunction to bind a media nonparty would therefore also require the nonparty to have been aware of the protective order at the time the court-protected information was obtained. ${ }^{251}$

\section{The "Aider and Abettor" Test}

A more simplistic, but possibly more accurate, analysis would subject a media nonparty who acquires confidential discovery information from a litigant to "aider and abettor" liability. ${ }^{252}$ Since the purpose of aider-abettor liability is to enable an injunction to be enforced against "all persons acting in conjunction with the enjoined party," thereby negating the possibility of "independent activity," the critical factual inquiry would examine the extent of collusion between the media nonparty-"abettor" and the litigant. ${ }^{253}$

The term "collusion" is defined as an "agreement between two or more persons to defraud a person of his rights by the forms of law, or to obtain an object forbidden by law."254 To collude, then, requires an understanding that one is colluding. Given that the information would be received from one of the litigants, the power to bind the media nonparties from further dissemination would seem to rely on the Golden State Bottling Co. "knowledge" requirement: ${ }^{255}$

acquiring with knowledge that the wrong remains unremedied the employing enterprise which was the locus of the unfair labor practice, may be considered in privity with its predecessor for purposes of 65(d)" (emphasis added)).

251 The task of inculpating the media nonparty for violating a protective order based on knowledge of the order would not occur without its share of problems. Chief among these problems would be the necessity for a hearing to determine how the materials were obtained. This hearing would require putting reporters on the stand and interrogating them as to their investigating methods. See, e.g., Procter \& Gamble Co. v. Bankers Trust Co., 900 F. Supp. 186, 188 (S.D. Ohio 1995) (discussing the hearing held "to determine whether the protected, confidential information obtained by [the media nonparty] was acquired lawfully and independently of the discovery process"). More importantly, the "freedom" of the press would ultimately be implicated by the hearings, which would require reporters to reveal how they received the protected materials, thereby giving up their confidential sources. See MacLachlan, supra note 191, at Al.

${ }^{252}$ See Alemite Mfg. Corp. v. Staff, 42 F.2d 832, 832 (2d Cir. 1930) ("We agree that a person who knowingly assists a defendant in violating an injunction subjects himself to civil as well as criminal proceedings for contempt.").

${ }_{235}$ Binding Nonparties to Injunction Decrees, supra note 217, at 724 . "Since the purpose of the aider and abettor extension is to make the injunction effectual against all persons acting in conjunction with the enjoined party, ... the crucial element is the existence of collusion between the abettor and the party defendant." Id. (footnote omitted).

${ }^{254}$ BLACK's LAW Dictionary 264 (6th ed. 1990).

${ }^{235}$ See supra notes 250-51 and accompanying text. 
whether the media nonparty had "knowledge" of the protective order at the time it received the information. If the media nonparty knew of the protective order at the time it received the material, further dissemination would arguably constitute collusion with the litigant who originally gave the media access and violated the protective order. ${ }^{256}$ This "collusion" would be derived from the recognition that, upon receiving the court-protected materials, the protective order had been violated once; any further dissemination would violate the protective order a second time. If the media nonparty did not have knowledge of the protective order at the time it received the materials, it arguably was not aiding or abetting the defendant because the nonparty had a wholly "independent" interest in the material. ${ }^{257}$

${ }^{256}$ The "aider and abettor" classification is not entirely accurate, however. A media nonparty may have only an incidental interest in colluding with the litigant to violate the protective order-that is, the media nonparty clearly may have its own financial interest in publishing the information. See Binding Nonparties to Injunction Decrees, supra note 217, at 725. The First Circuit, however, decided a case, which determined that this distinction was immaterial for purposes of "aiding and abetting" a violation of an injunction. See Reich v. United States, 239 F.2d 134, 137-38 (1st Cir. 1956) (finding a psychiatrist in contempt for assisting a defendant in procuring a scientific product in violation of an injunction), cert. denied, 352 U.S. 1004 (1957).

${ }^{257}$ In spite of the foregoing analysis, it is arguable that the court could issue an injunction enjoining a media nonparty from further dissemination without any of the previously discussed limitations. Given the property interest in confidential business information covered by a protective order, see supra Parts II.B, III.A, the court may be able to issue an in rem injunction. See Golden State Bottling Co. v. NLRB, 414 U.S. 168, 179 (1973) ("Persons acquiring an interest in property that is a subject of litigation are bound by, or entitled to the benefit of, a subsequent judgment, despite a lack of knowledge."); see also United States v. Dean Rubber Mfg. Co., 71 F. Supp. 96, 98 (W.D. Mo. 1946) (noting that "[i]t is only injunctions, acting in rem, that bind successive ownerships of the rem"). Irrespective of Rule 65 (d), courts have continued to issue injunctions in rem against those parties, or nonparties, who threaten that property interest. See United States v. Hall, 472 F.2d 261, 267 (5th Cir. 1972) (“[C]ourts have continued to issue in rem injunctions notwithstanding Rule 65(d), since they possessed the power to do so at common law and since Rule 65(d) was intended to embody rather than to limit their common law powers."). Because in rem injunctions adjudicate conflicting claims to property interests and have thus been subject to physical attachment by the court, these injunctions also lack the Rule 65(d) due process requirement that the nonparty subject to the injunction have "actual knowledge" of the order. See JACK H. FRIEDENTHAL ET AL., CIVIL PROCEDURE $§ 3.8$, at 114 (1985). Therefore, in rem injunctions, unlike Rule 65(d) injunctions, are effective "against all the world." Arndt v. Griggs, 134 U.S. 316, 320 (1890) (quoting Watson v. Ulbrich, 24 N.W. 732 (1885)). Given the overlap between speech and property claims in the protective-order context, however, in rem injunctions without "actual" notice would probably violate due process notice requirements. 


\section{A PROPOSAL FOR ENFORCING PROTECTIVE ORDERS AGAINST MEDIA NONPARTIES}

Having explored legal doctrines that limit the use of certain commercial information by nonparties because of the coexisting private property interest in such information, ${ }^{258}$ it appears that a nonparty who has acquired confidential discovery materials may be within the jurisdictional reach of the courts. ${ }^{259}$ The suggestion that protective orders may be enforced against media nonparties in certain situations requires further refining. For instance, a court may issue a protective order even when the corresponding property interest in the sealed material is suspect. Moreover, a media nonparty may acquire information under protective seal by many different means-such as buying the information from a litigant, or finding the information on a street corner-and not all of these methods enable a court to find the required link between a party and the media nonparty. Therefore, some guidance is necessary in order to know when an injunction issued against a media nonparty in possession of protective-order information is constitutionally valid.

\section{A. Developing a Standard That Reflects Both How Protective Order Information Is Acquired and How the Proprietary Interest Is Affected}

The power of a court to enforce its protective order against a media nonparty who has acquired sealed information turns on two issues: (1) whether an injunction will "reach" the nonlitigant, and (2) whether there are competing interests which would advise against the injunction.

\section{Injunctive Power Based upon How Protected Material Is} Acquired: The "Active Procurement" Standard

The scope of a court's injunctive power, as discussed above, depends on when the media nonlitigant had knowledge of the injunction, and how the media nonlitigant acquired the information. ${ }^{260}$ It is clear that the media nonparty must have notice of the protective order at the time it acquires the information. ${ }^{261}$ This test protects the

\footnotetext{
${ }^{25 s}$ See supra Part III.A.

259 See supra Part III.B.

${ }^{260}$ See id.

${ }^{261}$ See supra notes $250-51$ and accompanying text.
} 
media nonlitigant who gathers information and is later informed that the material is under protective seal.

The more difficult determination is the circumstances under which a media nonparty's method of acquiring the enjoined information should subject it to a court's injunctive power. Recall that a media nonparty must either be "legally identified" with a party to the order, or the media nonparty must "aid and abet" a violation to the order. These standards suggest a distinction between acquiring protected information by happenstance, and acquiring it directly from the opposing litigant. To distinguish between these two situations, and others that are more vague, a court should determine whether the media nonparty actively procured the information from the court or the litigant.

An active procurement standard relies on the notion that the media nonlitigant possessed the requisite knowledge of the protective order ${ }^{262}$ and nevertheless took some positive action to acquire the information. Positive action could encompass acts as simple as a phone call to the litigant's attorney, or as complex as the use of false pretenses to gather confidential material directly from the court. Actively acquiring material directly from a litigant or from the court comports more closely with the "legal identity" test and the "aider and abettor" standard than would a standard that does not restrict itself to active acquisition. Moreover, this standard is consistent with the idea that the media nonlitigant lacks an "independent" interest in the material because any arguable interest is derived from the parties' interests. To the extent that the media nonparty does actively acquire the information, then the required link between a nonparty and a party to the protective order can be established, and the injunctive power should "reach."

2. Injunctive Power Based upon Proprietary Interest:

"Bona Fide Trade Secret" Standard

The second issue to be analyzed is whether proprietary interests warrant the extension of protective-order enforcement to media nonparties, recognizing the First Amendment interests to the contrary. As discussed above, the Supreme Court has acknowledged the predominance of certain private property interests in intangible property even in the event of competing First Amendment inter-

${ }^{262}$ See id. 
ests. ${ }^{263}$ The proprietary interests, however, must be not only clearly established, but also substantial. ${ }^{264}$ Therefore, property interests that are incidental to owners' other interests will fail to provide support for injunctive relief in the face of competing First Amendment claims.

While the Supreme Court recognizes private property interests in certain intangibles like trade secrets, ${ }^{265}$ protective orders are not limited to sealing this type of information. Indeed, protective orders may cover information whose corresponding property interest may be only incidental. Determining this property interest is crucial because a media nonparty's ability to publish protective-order information may turn on the extent of this interest. ${ }^{266}$

In general, there are two basic justifications for requesting a protective order: adverse publicity, and confidential commercial information (including trade secrets). ${ }^{267}$ Because the justification used to issue a protective order is generally a good indicator of the property interest involved, these two justifications will be examined separately.

\section{a. Adverse Publicity}

Although litigants generally carry the burden of allowing the public to learn information which the litigant would rather keep private, ${ }^{268}$ occasionally a protective order may be issued under Rule 26(c)'s express authorization to protect a litigant generally from "annoyance, embarrassment, [or] oppression," which may result from the disclosure of details of a litigant's activities. ${ }^{269}$ In Cipollone $v$. Liggett Group, Inc., ${ }^{270}$ the Third Circuit addressed a request for a protective order to prevent adverse publicity. The Cipollone case involved multiple product liability actions against tobacco companies. The defendant companies asserted that although the discovery

${ }^{263}$ See supra Part III.A.

264 See supra Part III.A.3.

${ }^{265}$ See Ruckelshaus v. Monsanto Co., 467 U.S. 986, 1003-04 (1984) (determining that trade secrets constitute "property" for purposes of the Fifth Amendment's Takings Clause).

266 See supra Part III.A.3.

${ }^{267}$ See Francis H. HARE, JR., ET AL., CONFIDENTLALITY ORDERS 118, 129-35 (discussing grounds for requesting protective orders); Marcus, supra note 54, at 488-93 (discussing the standards for issuance of a protective order).

263 See HARE, supra note 267, at 135-36.

${ }^{269}$ FED. R. CIV. P. 26(c).

270785 F.2d 1108 (3d Cir. 1986). 
information did not contain trade secrets, it included materials which if made public would cause them annoyance and embarrassment sufficient to justify a protective order. ${ }^{271}$ Rather than decide whether a protective order should issue, the Third Circuit enunciated a standard to help the lower court determine whether a claim of embarrassment warranted a protective order: "[T]o succeed, a business will have to show with some specificity that the embarrassment resulting from dissemination of the information would cause a significant harm to its competitive and financial position." ${ }^{272}$ The Third Circuit thus virtually eliminated justifications for protective orders based on general claims of embarrassment and required a commercial litigant to show not only a certain level of specificity, but also that the specific embarrassment "will be particularly serious."273 Under Cipollone, a protective order may cover information which, if released, would cause "serious embarrassment" and financial harm to proprietary interests. ${ }^{274}$ While Cipollone is illustrative of the notion that protective orders can be issued after making the requisite showing based on embarrassment notions, it is important to note what the decision does not accomplish. It does not establish that the commercial litigant seeking the protective order has a proprietary interest in the information itself. In Cipollone, where the defendants acknowledged that the information sought to be covered did not contain trade secrets, the proprietary interest involved related solely to the effect that the public release of the information would have on their financial standing. ${ }^{275}$ This distinction is crucial when the protective-order information is now in the hands of a media nonlitigant. If a media nonlitigant has acquired material which is under protective order of the court, and the information is not linked to a property interest of a commercial litigant, then the First Amendment considerations will override any contrary arguments for enforcing the protective order. ${ }^{276}$ With respect to protective orders based on adverse publicity, litigants will find little support in enforcing these orders against media nonlitigants.

${ }^{271}$ See id. at 1121 .

${ }^{272} I d$.

${ }^{273} I d$.

274 See id.

${ }^{275}$ See id. ("The defendants assert that although the material they have turned over does not contain trade secrets, it does include materials the dissemination of which would cause them annoyance and embarrassment ....").

${ }^{276}$ See supra Part III.A.3. 


\section{b. Confidential Commercial Information, Including Trade Secrets}

While confidential commercial information and trade secrets often directly implicate proprietary interests, these interests vary in substantive force. For instance, while few would doubt the validity of Coca-Cola's proprietary interest in its secret formula, many would question the intrinsic value of an oil company's lists of dissatisfied customers. Yet both interests justified the authorization of protective orders $^{277}$ pursuant to Rule 26(c)(7): protecting "a trade secret or other confidential research, development or commercial information." ${ }^{278}$ By its explicit terms, Rule 26(c)(7) protects a source of information broader than only "true" trade secrets. ${ }^{279}$

The consequence of Rule 26(c) (7)'s breadth of coverage is that some confidential information sealed by a protective order-namely that information failing to qualify for trade secret status-has a less clearly recognizable proprietary interest. The essence of a trade secret is the ability to gain an advantage over competitors who lack similar knowledge. ${ }^{280}$ Presumably, the use of protective orders guards a trade secret's confidentiality during the discovery stage of litigation, which maintains its proprietary value. Contrast such a use of protective orders with the use of protective orders issued to prevent the disclosure of confidential information that is not a trade secret, but nonetheless could injure a corporation's reputation and

277 See Coca-Cola Bottling Co. v. Coca-Cola Co., 107 F.R.D. 288, 289 (D. Del. 1985) (describing, in a suit that attempted to force the Coca-Cola, Co. to disclose its secret formula pursuant to a protective order, the extent to which Coca-Cola Co. protected the formula); American Oil Co. v. Pennsylvania Petroleum Prods. Co., 23 F.R.D. 680, 683-84 (D.R.I. 1959) (showing that Rule 26(c)(7)'s equivalent predecessor, Rule 30 (b), allowed protective orders to protect lists of dissatisfied customers).

${ }^{278}$ FED. R. CN. P. 26(c)(7).

${ }^{279}$ It should be noted, however, that some courts have looked to the Restatement of Torts definition of trade secrets to determine whether a protective order should issue. See, e.g., Smith v. BIC Corp., 121 F.R.D. 235, 239-40 (E.D. Pa. 1988) (noting that Pennsylvania courts, in determining whether a protective order should issue, have relied on $\$ 757$ of the Restatement of Torts for the definition of "trade secret"); Waelde v. Merck, Sharp \& Dohme, 94 F.R.D. 27, 28-29 (E.D. Mich. 1981) ("Plaintiff and defendant agree that the criteria for determining whether information is a trade secret are set out in the Restatement of Torts $\left.\S 757 .{ }^{n}\right)$; United States v. IBM, 67 F.R.D. 40, 46-47 (S.D.N.Y. 1975) ("In [protecting information under Rule 26(c)] the court will be guided by considerations commonly employed when determining if certain information rises to the level of a trade secret such as is embodied in Section 757 of the Restatement of Torts.").

${ }^{280}$ See RESTATEMENT (FIRST) OF TORTS $\$ 757$ (1939) (providing that trade secrets "may consist of any formula, pattern, device or compilation of information which is used in one's business, and which gives him an opportunity to obtain a competitive advantage over competitors who do not know it or use it"). 
cause a decline in its stock value. ${ }^{281}$ In the latter situation, the information itself has no proprietary interest outside the effect it may have on the corporation's capital stock value. Therefore, while some protective orders may cover certain confidential information that is undoubtedly a trade secret and thus proprietary in nature, ${ }^{282}$ "this subject-matter category is broad enough to include a wide variety of business information," ${ }^{283}$ not all of which may reach the level of "property."

The complexity of identifying property interests in confidential information covered by a protective order is exacerbated by the fact that courts routinely approve stipulated orders for large volumes of documents using relaxed standards. ${ }^{284}$ This is generally due to the interest in facilitating the efficient and cooperative exchange of discovery materials by eliminating additional procedures for sorting the "truly" confidential documents from those that are not. ${ }^{285}$ The consequence is that some discovery material covered by a protective order may not be deserving of "property" status. If this were the case, the First Amendment would be more directly implicated by an injunction restraining the media nonparty.

Therefore, the analysis of the two basic justifications for protective orders appears to describe three levels of property interests:

${ }^{281}$ See Littlejohn v. BIC Corp., 851 F.2d 673, 685 (3d Cir. 1988). In Littlejohn a protective order was issued despite the fact that documents of the defendant were not trade secrets. The general commercial interest was the desire to preserve corporate reputation. The court found that the protection to which the information was entitled at the evidentiary stage was less than that to which a "true" trade secret was entitled. See id.

${ }^{282}$ See, e.g., Coca-Cola Bottling Co. v. Coca-Cola Co., I07 F.R.D. 288, 289 (D. Del. 1985) (acknowledging the formula for Coca-Cola to be "one of the best-kept trade secrets in the world").

${ }^{283}$ Zenith Radio Corp. v. Matsushita Elec. Indus. Co., 529 F. Supp. 866, 890 (E.D. Pa. 1981). In a footnote, the Zenith court described a list of different types of business information which had been covered by protective orders in previous cases. These included financial statements, customer lists and lists of dissatisfied customers. See id. at 890 n.42.

${ }^{284}$ See HARE, supra note 267, at 116 (noting that "some courts have honored [stipulated-order] requests" while others still required good cause); see also Schmitt, supra note 123, at B1 ('Judges often 'rubber stamp' [stipulated confidential] agreements ... though a million pages of documents may be involved even in a routine matter.'" (quoting Boris Feldman, an attorney for high-tech companies)).

${ }^{285}$ See Schmitt, supra note 123, at B1 ("Judges and lawyers would have to spend an inordinate amount of time sorting through an avalanche of documents to determine what really should be kept confidential."); see also The O.J. Gag Rule, WALL ST. J., Oct. 5,1995 , at A14 ("Parties routinely file mountains of documents with the court, which in turn routinely grants requests to deny access to avoid the job of actually wading through them to evaluate their confidentiality."). 
"Bona fide" trade secrets with the highest property interest, other confidential information with an intermediate level of property interests, and adverse publicity claims with the lowest level of interests. Because of the difficulty in discerning the varying property interests in the intermediate level, and the importance of the First Amendment interests at stake, protective-order enforcement against a media nonlitigant should be limited to bona fide trade secrets. These trade secrets can be distinguished from other confidential financial information by using the definitions provided by the First Restatement of Torts ${ }^{286}$ and the Uniform Trade Secrets Act. ${ }^{287}$ Some courts have already adopted the definitions provided by the Restatement in formulating standards for issuance of protective orders. ${ }^{288}$ Implementing a bona fide trade secret determination would thus be a natural transition.

\section{CONCLUSION}

The issue of whether a court may prevent or sanction a media nonparty for publishing materials that are under a protective order will not be resolved without severe repercussions. The media has a clear interest in challenging any decision that may encroach upon their right as a free press in an open society. ${ }^{289}$ At the same time, the lower courts have a legitimate interest in administering and maintaining control of the cases before them. ${ }^{290}$ Moreover, the private litigants may have any number of interests at stake that could be implicated by allowing nonparty dissemination. The one certainty

${ }^{286}$ See RESTATEMENT (FIRST) OF TORTS $\$ 757 \mathrm{cmt}$ a (1939) ("The significant difference of fact between trade secrets and processes or devices which are not secret is that knowledge of the latter is available to the copier without the use of improper means to procure it, while knowledge of the former is ordinarily available to him only by the use of such means.").

${ }^{287}$ See Uniform Trade Secrets Act § 1, 18 U.S.C. § 1905 (1994).

${ }^{283}$ See, e.g., United States v. IBM, 67 F.R.D. 40, 46-47 (S.D.N.Y. 1975) (reciting the factors of secrecy listed in the Restatement).

${ }^{289}$ See The Story You Should Be Reading, BUS. WK., Oct. 2, 1995, at 150 ("The power to censor is the power to regulate information. It is unacceptable in a market democracy.").

${ }^{290}$ See Wood v. Georgia, 370 U.S. 375, 383 (1962) ("We start with the premise that the right of courts to conduct their business in an untrammeled way lies at the foundation of our system of government and that courts necessarily must possess the means of punishing for contempt when conduct tends directly to prevent the discharge of their functions."); see also The Story You Should Be Reading, supra note 289, at 150 ("The federal judiciary must have the right to set and enforce rules."). 
in this debate is that the rationale underlying the protective order will be vitiated if nonparties are allowed the dissemination right.

The challenge facing the courts is to utilize their broad discretion in approving protective orders wisely. ${ }^{291}$ Because requiring a court to differentiate confidential from nonconfidential material would undermine the interest in judicial efficiency, a media nonparty who has acquired court-protected material that it believes is outside the realm of "property" should request a modification of the order to avoid the consequences of dissemination and further violation of the order. ${ }^{292}$

The facts of the Business Week case serve to illustrate the multitude of interests involved when prior restraint and protective-order issues are involved. Although this case has recently been overturned by Sixth Circuit Court of Appeals based on prior restraint grounds, ${ }^{293}$ this decision is not necessarily inconsistent with the proposal in this Comment. First, it is debatable whether Business Week had actual knowledge of the protective order before it acquired the disputed information, ${ }^{294}$ which calls into question satisfaction of an active procurement standard. Even assuming that Business Week was aware of the protective order before it acquired the information, the information sought to be published falls short of a bona fide trade secret. Based on the information eventually published in Business Week, ${ }^{295}$ the protective order in that case seems to have been imposed primarily to stem the financial and competitive harm to the litigants that would be caused by publication of the potentially

291 See Marcus, supra note 54, at 489-90 (arguing that "trying to narrow the grounds for protection under Rule 26(c) unduly constricts the broad discretion the rule vests in district courts to superintend the discovery process"); see also Post, supra note 48, at 225 ("Although Rule 26(c) makes no effort to specify "narrow, objective and definite standards' to govern the issuance of restraining orders, any attempt to do so would likely cripple trial courts' ability effectively to manage the pretrial exchange of discovery information." (quoting Shuttlesworth v. Birmingham, 394 U.S. 147, 151 (1969))).

${ }_{292}$ See In re "Agent Orange" Prod. Liab. Litig., 104 F.R.D. 559, 576 (E.D.N.Y. 1985) (denying a challenge by a nonparty broadcaster to access discovery documents in a litigation involving Vietnam War veterans and exposure to herbicides); see also HARE, supra note 267, at 144-47 (discussing modification of protective orders).

293 See Procter \& Gamble Co. v. Bankers Trust Co., 78 F.3d 219, $224-27$ (6th Cir. 1996).

${ }^{294}$ Compare id. at 223 (noting that "[n]either the partner [who turned over the information] nor the journalist appeared to know that the material was under seal") with id. at 229 (Brown, J., dissenting) (noting that "[a]lthough aware of [the protective] order, Business Week reporters managed to get the documents").

${ }^{295}$ See Kelly Holland, et al., The Bankers Trust Tapes, BUS. WK., Oct. 16, 1995, at 106. 
embarrassing material, rather than to prevent the disclosure of trade secrets. ${ }^{296}$ The Sixth Circuit reversal, therefore, does not settle the issue. It only stirs the debate.

${ }^{296}$ Among the information published were excerpts from the 6,500 tape recordings of Bankers Trust confidential conversations. See id. 
